DEUİFD Din Piskolojisi Özel Say1s1 / 2016, ss. 41-81.

\title{
MEME KANSERLİ HASTALARDA AĞRI VE UZUV KAYBINA (MASTEKTOMİ) BAĞLI DEPRESYON DÜZEYLERİNIN YAŞAM KALİTESİ VE DİNDARLIK İLE İLİŞKİSİ
}

\begin{abstract}
Ahmet Albayrak ${ }^{* *}$, Emine Kurt ${ }^{* * *}$
ÖZ

$\mathrm{Bu}$ araştırmanın amacı, meme kanseri kadın hastalarda ağrı ve mastektominin neden olduğu uzuv kaybına bağlı depresyon ile yaşam kalitesi ve dindarlık arasındaki ilişkileri belirlemektir. Araştırmanın örneklemini, Bursa Ali Osman Sönmez Onkoloji Hastanesi Radyasyon Onkolojisi Polikliniği’nden seçilen 360 meme kanseri kadın hasta oluşturmaktadır. Araştırmada kullanılan ölçme araçları; Beck Depresyon Envanteri, EORTC QLQ C-30 Yaşam Kalitesi Ölçeği, Ok-Dini Tutum Ölçeği ve Sayısal Ağrı Skalası'ndan oluşmaktadır.

Araştırma sonuçlarına göre; dini tutum ile ağrı algısı arasında anlamlı bir ilişki bulunmamıştır. Dini tutum ve dini tutumun tüm alt boyutlarındaki puan ortalamasi; olumlu beden algisina sahip hastalarda, olumsuz beden algisina sahip hastalardan anlamlı olarak daha yüksektir.

Dini tutum ile depresyon arasında negatif yönde anlamlı bir ilişki olduğu bulunmuştur. Dini tutum (toplam) ile yaşam kalitesinin Genel İyilik Hali boyutu arasında pozitif yönde; dini tutumun davranış alt boyutu ile yaşam kalitesinin Fonksiyonel Durum ve Genel İyilik Hali boyutları arasında da pozitif yönde anlamlı bir ilisski olduğu bulunmuştur.
\end{abstract}

Anahtar Kelimeler: Meme Kanseri, Mastektomi, Ağr1 Alg1s1, Beden Alg1s1, Depresyon, Yaşam Kalitesi, Dini Tutum, Dindarlık.

\section{RELATIONSHIP BETWEEN DEPRESSION LEVELS DUE TO PAIN \\ AND LOSS OF LIMB (MASTECTOMY) AND QUALITY OF LIFE AND RELIGIOSITY IN PATIENTS WITH BREAST CANCER}

\section{ABSTRACT}

The aim of this research is to determine the relationships between depression due to pain, and loss of limbs due to mastectomy and quality of life, and religiousness of women with breast cancer. Sample of the study consisted of 360 women with breast cancer selected from Ali Osman Sönmez Oncology

** Uludağ Ün. İlahiyat Fak. Din Psikolojisi AD Öğretim Üyesi (Doç. Dr.)

*** Din Psikolojisi Bilim Uzmanı

Makalenin Hakemlere Gönderiliş Tarihi : 16/11/2015

Makalenin Hakemlerden Geliş Tarihi : 13/12/2015 
Hospital, Radiation Oncology Clinic. The measures used in the study included the Beck Depression Inventory (BDI), European Organization for Research and Treatment of Cancer Quality of Life Questionnaire (EORTC QLQ C-30), the OK-Religious Attitude Scale (RA), and the Numeric Rating Scale (NRS) for pain.

According to results; no significant correlations were found between a religious attitude (RA) and the pain perception. Mean scores of the RA and subscales of RA of patients with a positive body perception were higher than that of patients with a negative body perception.

There was a significant negative correlation between the religious attitude (RA) and depression. A significant positive correlation was found between the RA (total) and a global health scale of quality of life. In addition, a significant positive correlation was found only between behavior subscale of (RA) and a functional and the global health scales of quality of life.

Key Words: Breast Cancer, Mastectomy, Pain Perception, Body Perception, Depression, Quality of Life, Religious Attitude, Religiosity.

\section{GİRIş}

İnsan, biyolojik yapısının ötesinde psikolojik, sosyolojik ve spiritual/manevi boyutları da olan kompleks bir varlıktır. Son yıllarda insan odaklı yapılan çalışmalarda, bu bütüncül yapının önemine dikkat çekilmektedir. Özellikle tıp ve sağlık alanında tedaviye yönelik girişimlerde hastalıkların bedensel etkileri yanında psikolojik ve sosyal alanlardaki olumsuz etkilerinin azaltılması ve yaşam kalitesinin en iyi düzeye çıkarılmasına ilişkin disiplinler arası yaklaşımlar gündemdedir. Ayrıca fiziksel ve psikolojik sağlık ile sosyal refahın yanında sorgulayan, hayatta anlam ve amaç arayan, varoluşsal kayg1 ve korkular yaşayan insanın spiritual/manevi ya da aşkın yönünün yaşamda doyum bulma, mutluluk ve içsel huzurun sağlanmasında aktif rol üstlendiği görülmüştür. Dini inanç ve spiritual/manevi değerlerin ise insanın varoluşsal, aşkın yönünü temsil ettikleri ve fiziksel, psikolojik ve sosyal boyutlar ile bütüncül bir ilişki içinde oldukları anlaşılmaktadır.

Son yıllarda yapılan araştırmalarda dini inanç ve spiritual/manevi değerlerin, bedensel ve ruhsal sağlık ile önemli ilisskiler gösterdiği tespit edilmiştir. $\mathrm{Bu}$ konuda yapılan ampirik çalışmalar, dindarlık düzeyi (samimi bir inanç, ibadete devam, dua etme, kutsal metinleri okuma, vs.) yüksek olan kişilerin, dindarlık düzeyi düşük olan kişilere oranla 
psikolojik açıdan daha iyi durumda olduklarını, hayattan daha çok mutmain olduklarını, daha iyimser bir anlayışa sahip olduklarını, buna karşılık daha az stres, depresyon ve kaygı yaşadıklarını, stresle daha iyi bir şekilde başa çıtıklarını ve daha az intihara teşebbüs ettiklerini göstermektedir. Ayrıca samimi dini inanç ve uygulamaların, sadece ruh sağlı̆̆1 açısından değil, beden sağllğ̆1 açısından da önemli olduğu ortaya çımıştır.

Dindarlık ve maneviyatın, beden sağlığ1 üzerindeki araştırmalarının kapsamına kalp ve damar sistemi hastalıkları, her tür kanser hastalığı, romatoid artrit, alkol kullanım bozukluğu, çeşitli ağrı ve acılar gibi birçok fiziksel rahatsızlıklar girmektedir. Bu rahatsızlıkların önemli bir kısmının, kanser hastalığında olduğu gibi aynı zamanda psikolojik yönleri de bulunmaktadır. ${ }^{2}$ Günümüzde önemli bir sağlık problemi olan ve oldukça yaygın bir şekilde görülen kanser, din psikolojisinin önemli çalışma alanlarından biri olmuştur. Kanser hastalığı, özellikle belirsizlikler içeren, ağrı ve acı içinde ölümü çağrıştıran, suçluluk, terk edilme, kaos, panik ve kaygı uyandıran bir hastalık olarak alg1lanmaktadır. ${ }^{3}$ Hem fiziksel ve hem de ruhsal anlamda pek çok zorlukla karşılaşan kanser hastalarında, bu kriz dönemine adapte olmada, din ve maneviyatın önemli bir rol oynadığını gösteren pek çok çalışma vardır. Her tür kanser hastası üzerinde yapılan bu çalışmaların büyük çoğunluğunda, dinin kanser hastaları için önemli olduğu ve hastalıkla başa çıkmada onlara yardımcı olduğu belirtilmiştir. ${ }^{4}$

Uluslararası Kanser Ajansı'nın 2012 verilerine göre; Dünya'da toplam 14,1 milyon yeni kanser vakası gelişmiş ve 8,2 milyon kansere

1 Mustafa Köylü, "Ruh ve Beden Sağlığı ile Din İlişkisi Üzerine Yapılan Araştırmaların Bir Değerlendirmesi”, Ondokuz Mayıs Üniversitesi İlahiyat Fakültesi Dergisi, S. 28, Samsun 2010, s. 6.

2 Ümit Horozcu, "Tecrübi Araştırmalar Işığında Dindarlık ve Maneviyat ile Ruhsal ve Bedensel Sağlık Arasındaki İlişki”, Milel ve Nihal, C. VII, S. 1, İstanbul 2010, s. 214.

3 Sedat Özkan, "Meme Kanserli Hastaya Psikolojik Yaklaşım, Yaşam Kalitesi", Meme Kanseri, ed. Erkan Topuz, İstanbul Üniversitesi, Onkoloji Enstitüsü Yayınlar1, 1997, s. 502.

4 Allen C. Sherman - Stephanie Simonton, "Religious Involvement Among Cancer Patients", Faith and Health, ed. Thomas G. Plante - Allen C. Sherman, The Guilford Press, New York, 2001, s. 167. 
bağlı ölüm olmuştur. Uluslararası Kanser Ajans1, özellikle meme kanserindeki artışa dikkat çekmiştir. Meme kanseri, kadın kanserleri içinde en fazla görülen ve en fazla ölüme neden olan kanserdir. Dünyada kanser olan her 4 kadından birinin ise meme kanseri olduğu tespit edilmiştir. $^{5}$

Meme kanseri, kadınlarda dişiliği ve cinselliği sembolize eden uzvun kaybına bă̆lı olarak, diğer kanser türlerine göre kadının ruhsal durumunu daha çok etkilemektedir. ${ }^{6}$ Dolayısıyla kadınlarda meme kanseri biyolojik, ruhsal, sosyal, çevresel, ailesel, psikososyal, psikoseksüel çok boyutlu bir olgu olduğu gibi aynı zamanda bir yaşam, kimlik ve varoluş krizi olarak da kendini göstermektedir. ${ }^{7}$ Yapilan araştırmalar gözden geçirildiğinde; meme kanseri tanı ve tedavisinde hastalarda anksiyete, depresyon, öfke, gelecek hakkında belirsizlik, umutsuzluk, çaresizlik, kanserin tekrarlayacağ1 korkusu, benlik saygisının azalması, beden imajının bozulması, ölüm korkusu gibi pek çok psikolojik sorunların ortaya çıkabildiği görülmektedir.

Kanser hastalarında hayatın anlamını bulmada, hastalığın sıkıntı ve zorlukları karşısında sabretme ve dayanma gücü oluşturmada din ve dindarlığın önemli rol oynadığ1 düşünülmektedir. Bu konuda çalışma yapan Musick ve arkadaşlanna göre din hastalığın daha az zararlı algılanmasını neden olabilir. Kutsal kitaplardaki birçok kıssa, zorluk ve sıkıntı zamanlarında güçlü bir inancın önemini göstermektedir. Zor zamanlarda Allah ile beraber olan, başına gelen musibetlere sabreden kişiler, gelecek dünyada mükâfat göreceğine inanırlar. İşte dinin kanserle olan ilişkisi burada ortaya çıkar. Dindar kişi, Allah'ı zor ve sıkıntılı zamanlarda kendisi için en iyi yardımcı olarak görür ve ölümü daha rahat

5 T.C. Sağlık Bakanlığı Türkiye Halk Sağlı̆̆1 Kurumu Kanser Daire Başkanlığı, 2009 Kanser Insidanslar1, GLOBOCAN 2012, http://www.kanser.gov.tr/dairefaaliyetleri/kanser-istatistikleri.html, (07.04.2014)

6 Veysi Ceylan, Meme Kanseri Olan Hastalarda Tanı Sonrası Psikososyal Sorunlar, Dicle Üniversitesi Tıp Fakültesi Psikiyatri Anabilim Dalı, (Yayımlanmamış Uzmanlık Tezi), Diyarbakır, 2009, s. 12.

7 Özkan, a.g.e., s. 501. 
kabullenir. "İnsanların hemen çoğunda dua ve ibadet yapmak için en kuvvetli eğilim savaş, deprem, hastalık, kaza... gibi çok büyük maddi yıkıntılar içinde, ölümle yüz yüze bulunduklarında ve özellikle asıl kendi ölümleri karşısında kendisini göstermektedir." Böyle durumlarda, dindar insan merhamet edici Tanrı'dan yardım ister. Başka bir ifadeyle, Tanrı'ya sığınarak ve ondan destek alarak zorluklar karşısında sabır ve metanet gösterme eğilimi içinde olan birey kendini daha güçlü hisseder ve zorluklarla daha kolay baş eder. ${ }^{10}$

Kanser gibi “uç durumlarda insanda, varllğın tamamen Allah'a ait olduğu duygusu uyanmaktadır. Arzu ile tatmin arasına bir uçurum açıldığ zaman, insan faniliğini keşfedebilmektedir. Varoluşu çöktüğü anda, kendi akıbetine kendi kendisinin sahip olmadığını kuvvetle tecrübe eden"11 insan, tek ve mutlak güce sığınır; acz ve çaresizliğini hissederek, $O$ büyük güce teslim olur. ${ }^{12}$

\section{ARAŞTIRMA}

\section{Araştırmanın Amacı ve Sınırlılıklar}

Meme kanseri kadın hastalarda, temel değişkenler olarak belirlenen dini tutum ile ağr1, uzuv kaybı, depresyon ve sağlıkta yaşam kalitesi arasındaki ilişkilerin tespit edilmesi bu araştırmanın amacını oluşturmaktadır.

Araştırmanın sınırlılıkları ise aşağıdaki gibi sıralanabilir:

8 M. A. Musick et al., "Religious Activity and Depression Among CommunityDwelling Elderly Persons with Cancer: The Moderating Effect of Race", The Journal of Gerentology, Vol. LIII, No. 4, Philadelphia 1998, ss. 218-227; Köylü, a.g.m., s. 22.

9 Hayati Hökelekli, Din Psikolojisi, Türkiye Diyanet Vakfı Yayınları, Ankara, 2010, s.90.

10 Halil Ekşi, Başa Çıkma, Dini Başa Çıkma ve Ruh Sağlığı Arasındaki İlişki Üzerine Bir Araştırma: Eğitim, İlahiyat ve Mühendislik Fakültesi Öğrencilerinin Karşılaştırılması, Uludağ Üniversitesi Sosyal Bilimler Enstitüsü, (Yayımlanmamış Doktora Tezi), Bursa, 2001, s. 7; Ali Ayten ve diğerleri, "Dini Başa Ç1kma, Şükür ve Hayat Memnuniyeti İlişkisi", Din Bilimleri Akademik Araştırma Dergisi, C. XII, S. 2, Samsun 2012, s. 48.

11 Hökelekli, a.g.e., s. 91.

12 Nevzat Tarhan, İnanç Psikelojisi, Timaş Yayınları, İstanbul, 2009, s. 201. 
1. Bu araştırma, belli bir zaman diliminde yapıldığ için boylamsal değil, kesitsel bir çalışmadır. Dolayısıyla araştırmadan elde edilen bulgular, araştırmanın yapıldığı 28 Ocak 2014-10 Nisan 2014 zaman aralığı ile sinırlıdır.

2. $\mathrm{Bu}$ araştırmadan elde edilen bulgular, araştırmanın yapıldığı yer olan Bursa Ali Osman Sönmez Onkoloji Hastanesi'ndeki meme kanseri kadın hastalar ile sinırlıdır.

3. Araştırmadan elde edilen bulgular, verilerin toplanması amaciyla kullanılan ölçme araçları ile sınırlıdır.

4. Meme kanserinin erkeklerde görülme oranının çok düşük olması sebebiyle çalışmaya erkek hastalar alınmamıştır. Dolayısıyla, cinsiyet faktörünün temel değişkenler üzerindeki etkisi araştırılamamıştır. Araştırma bulguları, kadın hastalar ile sınırlıdır.

5. Örneklem grubunu oluşturan hastaların, anket formunda yer alan maddelere verdikleri cevaplar, kendi görüss, alg1 ve değerlendirmelerini içerdiği için araştırmadan elde edilen bulgular, verilen cevaplar ile sinırlıdır.

\section{Hipotezler}

Araştırmanın amacı ve olası ilişkiler çerçevesinde belirlenen ana hipotez ve alt hipotezler şöyledir:

Ana hipotez: Meme kanseri kadın hastalarda dini tutum; ağrı algısı, uzuv kaybının kabullenilmesi, depresyon ve yaşam kalitesi üzerinde olumlu yönde etkide bulunur.

(H-1) Dini tutum ve dini tutumun davranış, duygu, ilişki boyutları ile ağrı algısı arasında negatif yönde anlamlı bir ilişki vardır.

(H-2) Olumlu beden algisına sahip hastaların dinî tutum düzeyleri ile dini tutumun duygu, davranış ve ilişki boyutlarındaki düzeylerine ait puan ortalamalarının olumsuz beden algısına sahip hastalara göre anlamlı derecede daha yüksektir.

(H-3) Dini tutum ve dini tutumun davranış, duygu, ilişki boyutları ile depresyon arasında negatif yönde anlamlı bir ilişki vardır. 
(H-4) Dini tutum ve dini tutumun davranış, duygu, ilişki boyutları ile yaşam kalitesi fonksiyonel durum ve genel iyilik hali boyutları arasında pozitif yönde anlamlı bir ilişki vardır.

(H-5) Dini tutum ve dini tutumun davranış, duygu, ilişki boyutları ile yaşam kalitesi semptom kontrolü boyutu arasında negatif yönde anlamlı bir ilişki vardır.

\section{Metot ve Uygulama}

$\mathrm{Bu}$ araştırmanın uygulama bölümünde, araştırma kapsamında gerekli bilgilerin toplanması amaciyla "örneklem survey" (tarama) modeli ve bu model içerisinde yer alan "anket tekniği" kullanılmıştır. Araştırmada, anket uygulamasından elde edilen veriler, parametrik olan istatistiksel analiz teknikleri ile test edilmiştir.

Araştırmada, ilgili konularda uzmanların görüşlerinden de istifade edilmiştir. Özellikle çalışmanın tıbbi yönü de dikkate alınarak araştırmanın planlama, uygulama ve değerlendirme aşamalarında (konunun seçimi, anket formunda hastalara ilişkin maddelerin tespit edilmesi, kanser hastalarıyla ilgili kullanılabilecek uygun ölçeklerin belirlenmesi, bulguların değerlendirilmesi vb.) bir onkoloji uzmanından bilgi, destek ve görüş alınmıştır.

Anketin, araştırma kapsamında belirlenen gruba uygulanabilmesi için Uludağ Üniversitesi Tip Fakültesi Klinik Araştırmalar Etik Kurulu ve Uludağ Üniversitesi Sosyal Bilimler Enstitüsü vasitasiyla Bursa İl Sağlık Müdürlüğü, Bursa Kamu Hastaneleri Genel Sekreterliği ve Bursa Ali Osman Sönmez Onkoloji Hastanesi Başhekimliği'nden gerekli resmi izinler alınmıştır. Anket uygulamasının, hastalar poliklinik ya da tedavi vb. uygulamalar için sıra beklerken, hastaların muayene, tetkik, tedavi vb. işlemlerini engellemeyecek şekilde, uygun ortam ve zamanda yapılmasına özen gösterilmiştir.

Araştırmada anket tekniği ile elde edilen nitel verilerin, sayısal değere dönüştürülerek bilgisayara aktarılmasında ve verilerin istatistiksel analizinde Statistical Package for Social Science "SPSS 18.0" paket programı kullanılmıştır. Bu çalışmada, tanımlayıcı istatistikler olan frekans, aritmetik ortalama gibi yöntemler kullanılarak örneklemin, araştırmada belirlenen değişkenlere göre dağılımı izlenmiştir. Ayrıca araştırmanın hipotezleri çerçevesinde, sürekli ve süreksiz değişkenler arasındaki ilişkilerin tespitinde "Bağımsız İki Örnek T-Testi (Independent-Samples T-Test)"; iki sürekli değişken arasındaki doğrusal 
ilişsinin derecesinin belirlenmesinde "Pearson Korelasyon Katsayısı", araştırmada kullanılan ölçeklerin güvenirlik analizinde ise "Alfa Modeli (Cronbach Alpha Coefficient)" "13 kullanılmıştır.

\section{Evren ve Örneklem}

Araştırmanın evrenini, Bursa Ali Osman Sönmez Onkoloji Hastanesi'ne 1 yıl içinde başvuru yapan meme kanseri tanısı almış tüm kadın hastalar oluşturmaktadır. Hastane kayıtlarına göre, 2013 yılı içinde 3645 meme kanseri hastaya ait giriş kaydının olduğu tespit edilmiştir. Bu say1, araştırmanın evren büyüklüğü olarak kabul edilmiştir. Araştırmaya katılmayı kabul eden ve katılım kriterlerine uyan 360 meme kanseri kadın hasta ise bu araştırmanın örneklemini oluşturmuştur.

Araştırmada, belli bir örneklem seçim yöntemine gidilmemiştir. 28 Ocak 2014 - 10 Nisan 2014 tarihleri arasinda, Bursa Ali Osman Sönmez Onkoloji Hastanesi’nin Radyasyon Onkolojisi Polikliniği'ne tedavi ve kontrol amacıyla gelen, araştırmaya alınma kriterlerine uyan ve gönüllü olan meme kanseri kadın hastalar, bu çalışmaya dâhil edilmiştir. Araştırmaya alınma kriterleri ise meme kanseri tanısı almış kadın hasta olma, 18 yaş ve üzeri olma, iletişime ve işbirliğine açık olma, algilama ve iletişim bozukluğu olmama, anket maddelerini değerlendirmesine engel olacak düzeyde psikolojik hastalığ1 olmama, kendi isteği ile araştırmayı sonlandırabilme olarak belirlenmiştir.

Örneklem grubunun yaş aralı̆̆ının 30-81 ve yaş ortalamasının 54.69 olduğu belirlenmiştir. Örneklemin yaş gruplarına göre dağllımı ise şöyledir: \% 8.6's1 30-39; \% 23.1'i 40-49, \% 34.2'si 50-59, \% 24.2'si 60-69, $\%$ 9.4'ü 70-79 ve \% 0.6's1 80 yaş ve üzeri grupta yer almaktadır. Hastaların \% 3.3'ünün bekar, \% 76.4'ünün evli, \% 3.6'sının eşinden ayrilmış, \% 16.7'sinin ise eşinin vefat ettiği tespit edilmiştir. Araştırmaya katılan hastaların \% 13.9'unun okuma-yazma bilmediği, \% 7.8’inin herhangi bir okuldan mezun olmadığ1 ancak okuma-yazma bildiği, \% 58.9'unun ilkokul, \% 5.8'inin ortaokul, \% 9.7'sinin lise ve \% 3.9'unun üniversite mezunu olduğu belirlenmiştir. (Bkz. Tablo 1)

13 Bkz. Şeref Kalayc1, SPSS Uygulamal Cok Değiskenli Istatistik Teknikleri, Asil Yayın, Ankara, 2010, s. 74, 116, 133, 405. 


\begin{tabular}{|c|c|c|}
\hline \multicolumn{3}{|c|}{ Tablo 1. Hastalarn Sosyo-Demografik Özelliklerinin Dağılımı } \\
\hline Yaş Ortalaması & \multicolumn{2}{|c|}{54.69} \\
\hline \multicolumn{3}{|l|}{ YAŞ GRUPLARI } \\
\hline $30-39$ & 31 & 8.6 \\
\hline $40-49$ & 83 & 23.1 \\
\hline $50-59$ & 123 & 34.2 \\
\hline $60-69$ & 87 & 24.2 \\
\hline $70-79$ & 34 & 9.4 \\
\hline$\geq 80$ & 2 & 0.6 \\
\hline TOPLAM & 360 & 100.0 \\
\hline \multicolumn{3}{|l|}{ MEDENİ DURUM } \\
\hline Bekar & 12 & 3.3 \\
\hline Evli & 275 & 76.4 \\
\hline Eşinden Ayrilmış & 13 & 3.6 \\
\hline Eşi Vefat Etmiş & 60 & 16.7 \\
\hline TOPLAM & 360 & 100.0 \\
\hline \multicolumn{3}{|l|}{ EĞİTİM-ÖĞRENİM } \\
\hline Okuma-Yazma Bilmiyor & 50 & 13.9 \\
\hline Okuma-Yazma Biliyor & 28 & 7.8 \\
\hline İlkokul & 212 & 58.9 \\
\hline Ortaokul & 21 & 5.8 \\
\hline Lise & 35 & 9.7 \\
\hline Üniversite & 14 & 3.9 \\
\hline TOPLAM & 360 & 100.0 \\
\hline
\end{tabular}

Örneklemin hastalığa ilișkin bazı özelliklerinin istatistiksel dağılımı Tablo 2'de gösterilmiştir. Buna göre hastaların \% 23.9'u Evre I, \% 42.2'si Evre II, \% 16.4'ü Evre III ve \% 17.5’i Evre IV olarak bulunmuştur. Örneklemin \% 1.1'inin ameliyat olmadığ1, \% 1.7'sine rekonstrüksiyon, \% 36.4'üne meme koruyucu cerrahi ve \% 60.8'ine mastektomi uygulandiğ1 belirlenmiştir. Ayrıca kemoterapi sürecinin hastaların \% 71.9'unda tamamlandığı, \% 23.9'unda devam ettiği ve \% 15 'ine ise kemoterapi uygulanmadığ tespit edilmiştir. 


\begin{tabular}{|c|c|c|}
\hline \multicolumn{3}{|c|}{ Tablo 2. Hastaliğa İlişkin Özelliklerin Dağzlım } \\
\hline EVRE & & \\
\hline Evre I & 86 & 23.9 \\
\hline Evre II & 152 & 42.2 \\
\hline Evre III & 59 & 16.4 \\
\hline Evre IV & 63 & 17.5 \\
\hline TOPLAM & 360 & 100.0 \\
\hline \multicolumn{3}{|l|}{ AMELİYAT TİPİ } \\
\hline Ameliyat Olmamış & 4 & 1.1 \\
\hline Rekonstrüksiyon & 6 & 1.7 \\
\hline Meme Koruyucu Cerrahi (MKC) & 131 & 36.4 \\
\hline Mastektomi & 219 & 60.8 \\
\hline TOPLAM & 360 & 100.0 \\
\hline \multicolumn{3}{|l|}{ KEMOTERAPİ TEDAVİ SÜRECİ } \\
\hline Tamamlanmış & 259 & 71.9 \\
\hline Devam Ediyor & 86 & 23.9 \\
\hline Kemoterapi Uygulanmamış & 15 & 4.2 \\
\hline TOPLAM & 360 & 100.0 \\
\hline
\end{tabular}

Veri Toplama Araçları

Bu araştırmada veri toplamak amacıyla kullanılan ölçme araçları; Hasta Bilgi Formu, Beck Depresyon Envanteri (BDE), EORTC QLQ C30 Yaşam Kalitesi Ölçeği, Ok-Dini Tutum Ölçeği ve Sayısal Ağrı Skalası olarak belirlenmiştir.

\section{Hasta Bilgi Formu}

Anket formunun I. bölümünde bulunan "Hasta Bilgi Formu"nda, örneklemi oluşturan meme kanseri kadın hastalara ait "yaş, medeni 
durum, eğitim-öğrenim durumu, hastalık evresi, uygulanan tedaviler, ameliyat tipi vb.” özellikler sorgulanmıştır.

\section{Beden Algisının Değerlendirilmesi}

Araştırmada, hastaların beden algılarının değerlendirilmesi için kullanılan ölçeklerin ve değişkenlerin çokluğu sebebiyle özel bir ölçme arac1 kullanılmamıştır. Anket formunun "Hasta Bilgi Formu" bölümüne eklenen "ameliyat sonras1 fiziksel görüntüm beni rahatsız ediyor" yargisina; "Evet" olarak cevap verenlerin "olumsuz beden algisı"na sahip olduklar1 ve "1" puan aldıklar1, "hayır" olarak cevap verenlerin ise "olumlu beden algisı"na sahip olduklar1 ve "0" puan aldıklar1 varsayılmıştır. Böylece, bu madde ile hastaların ameliyat sonrası fiziksel değişime ve uzuv kaybına bağlı olarak oluşan beden algılarının değerlendirilmesi amaçlanmıştır.

\section{Beck Depresyon Envanteri (BDE)}

$\mathrm{Bu}$ araştırmada Beck ve arkadaşları tarafindan geliştirilen ve özgün adı "Beck Depression Inventory (BDI)" olan ölçeğin, Hisli (1988, 1989) tarafindan Türkçe'ye uyarlaması yapılmış olan 1978 versiyonu kullanılmıştır. ${ }^{14}$ Hisli'nin (1988), poliklinik hastalarılyla yaptığ geçerlik ve güvenirlik çalışmasında, Türk populasyonu için 17 ve üstündeki BDE puanının, tedavi gerektirebilecek depresyonu \% 90 üzerinde bir doğrulukla ayırt edebildiği belirlenmiştir. Hisli’nin (1988) çalışmasında, ölçeğin güvenirlik katsayısı madde analizinde 0.80 ve yarıya bölme tekniğinde ise 0.74 olarak hesaplanmıştır. ${ }^{15} \mathrm{Bu}$ araştırmada da BDE'nin güvenirlik analizinde Cronbach's Alpha katsayısı 0.74 olarak bulunmuş ve ölçeğin kesme noktası 17 puan olarak alınmıştır.

Dörtlü likert tipi olan ölçek, 21 belirti kategorisini içermektedir. Bunlar; duygu-durum, karamsarlık, başarısızlık, doyumsuzluk, suçluluk duygusu, cezalandırılma duygusu, kendinden hoşnutsuzluk, kendini suçlama, intihar düşüncesi, ağlama nöbetleri, sinirlilik, karasızlık, bedensel

14 Nesrin Hisli, "Beck Depresyon Envanterinin Geçerliliği Üzerine Bir Çalışma", Psikoloji Dergisi, C. 6, S. 22, Ankara 1989, ss. 118-126; Nesrin Hisli Şahin, "Beck Depresyon Envanterinin Üniversite Öğrencileri için Geçerliği, Güvenirliğì", Psikoloji Dergisi, C. 7, S. 23, Ankara 1989, ss. 3-13.

15 Hisli, "Beck Depresyon Envanterinin Geçerliliği Üzerine Bir Çalışma", a.g.m., ss. 118-126. 
imge, çalışmanin ketlenmesi, uyku bozukluğu, yorgunluk, iştah azalması, kilo kaybı, somatik yakınmalar ve cinsel dürtü kaybı olarak siralanabilir. Ölçekte yer alan her madde 0-3 arasında giderek artan puan alır. Her bir maddede tercih edilen seçeneklere göre toplam puan hesaplanır. Buna göre ölçekten alınabilecek en düşük puan $(21 \times 0) 0$, en yüksek puan ise (21 x 3) 63'tür. Ölçeğin uygulanması sırasında, her kategoride, o gün de dahil olmak üzere son bir hafta içinde kişinin kendisini nasıl hissettiğini, en iyi ifade eden 4 seçenekten birini işaretlemesi istenir. Ölçekten alınan toplam puanın yüksek olması, depresyon düzeyinin ve şiddetinin de yüksek olduğunu göstermektedir. ${ }^{16}$

\section{EORTC QLQ C-30 Yaşam Kalitesi ÖIçeği}

(The European Organization for Research and Treatment of Cancer, 30-Item Core Quality of Life Questionnaire - Avrupa Kanser Araştırma ve Tedavi Organizasyonu Yaşam Kalitesi Anketi)

EORTC QLQ C-30 yaşam kalitesi ölçeği, Aaronson ${ }^{17}$ ve arkadaşları (1996) tarafından geliştirilmiştir. Ölçek, Güzelant ve arkadaşları (2004) tarafindan Türkçe'ye uyarlanmış ve akciğer kanseri hastalarda geçerlik ve güvenirlik çalışması yapılmıştır. Ölçeğin, Türk toplumu için Cronbach's Alpha katsayısı $\geq 0.70$ olarak hesaplanmıştır. ${ }^{18}$

Kanser hastalarında genel sağlık durumu ve yaşam kalitesinin belirlenmesinde yaygın olarak kullanılan EORTC QLQ C-30 çok boyutlu bir ölçek olup fonksiyonel durum, semptomlar ve genel iyilik halinin

16 İskender Savaşır - Nesrin Hisli Şahin, Bilişssel-Davranış̧ Terapilerde Değerlendirme: Sık Kullamlan Ölçekler, Türk Psikologlar Derneği Yayınları, Ankara, 1997; Ahmet Alacacıoğlu, Kanser Hastası ve Hasta Yakınlarının Depresyon, Umutsuzluk ve Kayg1 Düzeylerinin Değerlendirilmesi, Dokuz Eylül Üniversitesi Tıp Fakültesi, (Yayımlanmamış Uzmanlık Tezi), İzmir, 2007, ss. 17-18.

17 N. Aaronson - S. Ahmedzai - B. Bergman, "For The European Organization For Research And Treatment Of Cancer Study Group On Quality Of Life. The European Organization For Research And Treatment Of Cancer Qlq-C30: A Quality Of Life Instrument For Use İn İnternational Clinical Trials İn Oncology", $J$ Natl Cancer Inst, Vol. LXXXV, N. 5, 1993, pp. 365-376.

18 A. Güzelant et al., "The European Organization for Research and Treatment of Cancer C-30: An Examination into the Cultural Validity and Reliability of Turkish Version of the EORTC QLQ-C30”, Eur J Cancer Care, Vol. XIII (2), 2004, pp. 135 144. 
sorgulandığ 1 toplam 30 sorudan oluşmaktadır. Fonksiyonel durum ölçeğinde; fiziksel fonksiyon, uğraş fonksiyonu, kavrama fonksiyonu, duygusal fonksiyon ve sosyal fonksiyon olmak üzere 5 alt ölçek yer almaktadır. Semptom ölçeğinde ise halsizlik, ağr1, bulantı-kusma değerlendirildiği gibi dispne (nefes darlığı), uykusuzluk, iştah kayb1, kontipasyon (kabızlık), diyare (ishal) ve maddi zorluklar da ölçülmektedir. İlk 28 soru, 4'lü likert tipi ölçek olup herbir maddenin aldığ1 puan; (1: Hiç, 2: Biraz, 3: Oldukça, 4: Çok) olarak değerlendirilir. 29 ve 30. sorularda ise hastalardan, kendilerine 1'den 7'ye (1: Çok Kötü, 7: Mükemmel) kadar bir rakam vererek "Genel İyilik Hali" değerlendirmesi yapmaları istenir. Hesaplama sonucunda ölçekte yer alan her boyut için 0-100 arası puan elde edilir. Fonksiyonel durum ve genel iyilik hali için yüksek puanlar, işlevsel olarak ve genel sağlık algısı açısından yaşam kalitesinin yüksek düzeyde olduğunu; semptom boyutunda ise yüksek puanlar, semptom derecesinin yüksek olduğunu ve yaşam kalitesinin düşük düzeyde olduğunu gösterir. ${ }^{19}$

$\mathrm{Bu}$ araştırmada, EORTC QLQ C-30 yaşam kalitesi ölçeğinin güvenirlik analizinde Cronbach's Alpha katsayısı 0.79 olarak bulunmuştur. Araştırmada kullanılan değişkenlerin çokluğu nedeniyle, yaşam kalitesi ölçeğini oluşturan yalnızca Fonksiyonel Durum, Semptom Kontrolü ve Genel Iyilik Hali boyutlarına ait puan hesaplamaları yapılmış, bu boyutlara ait alt boyutlar için puanlama yapılmamıştır.

\section{Ok-Dini Tutum Ölçeği (ODTÖ-2011)}

Ok (2011) tarafindan geliştirilmiş olan Dini Tutum Ölçeği, 5’li likert tipte olup, 8 madde ve 4 alt boyuttan (biliş, duygu, davranış ve ilişski) oluşmaktadır. Bilişsel boyutla kişinin dinle ilgili genel görüşünün nasıl olduğu, davranışsal boyutla kişinin davranışlarının dini değerler tarafindan ne düzeyde yönlendirildiği ve duygusal boyutla kişinin dinin duyguya hitap eden yönü tarafindan ne düzeyde etkilendiği ölçülmeye çalışılmıştır. Tutumun bu üç bileşeninin yanında, ölçülmek istenen tutum nesnesinin din olmasindan ve dinde de Tanri'nın merkezi bir yere sahip olmasından dolayı bu boyutlara bir de Tanrıyla ilişki boyutu eklenerek Ok-Dini Tutum Ölçeği 4 alt boyutu ölçmek için tasarlanmış

19 Güzelant et al., a.g.m., pp. 135-144. 
bulunmaktadır. ${ }^{20}$ "İslami bir kültürde dindarlığı ölçmek" için geliştirilen bu ölçeğin metrik özelliklerinin belirlenmesinde örneklem sayılan 930 ve 388 üniversite öğrencisinden oluşan iki farklı örneklem grubuyla yapılan çalışmalardan elde edilen veriler kullanılmıştır. Ölçeğin bütünü ve alt boyutları için iç tutarlılıklarını gösteren Cronbach's Alpha katsayıları; bütünü için 0.90; duygu alt boyutu için 0.87 , ilişki alt boyutu için 0.85 , biliş alt boyutu için 0.75 , davranış alt boyutu için 0.86 olarak bulunmuştur. $^{21}$

$\mathrm{Bu}$ araştırmada, dini tutum ölçeğinin iç tutarlllı̆̆ını gösteren Cronbach's Alpha değerleri; ölçeğin bütünü için 0.85 , duygu alt boyutu için 0.81 , ilişki alt boyutu için 0.84 , davranış alt boyutu için 0.82 olarak bulunmuştur. Araştırmada, dini tutum ölçeğinin biliş alt boyutunu oluşturan 5. (dinin gereksiz olduğunu düşünüyorum) ve 6. (dini inancin insanlara yararından çok zararı olduğunu düşünüyorum) maddeler, örneklemde yer alan tüm hastalar tarafından "hiç katılmıyorum" olarak işaretlenmiştir. Biliş boyutuna, tüm katılımcıların aynı cevabı vermelerinden dolayı, bu boyut ile diğer değişkenler arasında istatistiksel analiz yapılamamıştır. Ancak, biliş boyutunu oluşturan 5. ve 6. maddeler, ters kodlanarak, dini tutum ölçeğinin bütünü içinde puanlamaya dahil edilmiştir.

Araştırmada dini tutum ölçeğinde yer alan seçenekler; (1: Hiç katılmıorum), (2: Az katıllyorum), (3: Orta düzeyde katıliyorum), (4: Çok katılıyorum), (5: Pek çok katılıyorum) şeklinde puanlanmıştır. Buna göre ölçekten alınabilecek en düşük puan " $1 \mathrm{x} 8=8$ ", en yüksek puan ise " $5 \times 8=40 "$ dır. Alt boyutlarda ise alınabilecek en düşük puan " $1 \times 2=2$ ", en yüksek puan ise " $5 \times 2=10$ " dur. Dini tutum ölçeğinde, puanların yüksek olmas1, dini tutum düzeyinin de yüksek olduğunu göstermektedir.

20 Üzeyir Ok, "Dini tutum Ölçeği: Ölçek Geliştirme ve Geçerlik Çalışması", Uluslararası Insan Bilimleri Dergisi, C. VIII, S. 2, Sakarya 2011, s. 535.

21 Ok, a.g.m., s. 528. 


\section{Sayıal Ağrı Skalası}

Sayısal ölçekler ${ }^{22}$, ağr1 şiddetinin sayısal olarak belirlenmesinde en sık kullanılan ve kullanımı en basit olan ölçme araçlarıdır. Bir cetvel üzerinde 0-10 veya 0-100 arasında sayıların yer aldığ1 "Sayısal Ağn1 Skalası"nda, "0" ağr1 yokluğunu, "10" ya da "100" ise şiddetli dayanılmaz ağriyı tanımlar. ${ }^{23}$ Sayısal ölçeklerin, ağrı şiddetini tanımlama, puanlama ve kayıtta sağladıkları kolaylıklar nedeniyle daha çok tercih edilmektedirler. Fakat bazı araştırmalarda, hastaların algılanan ağıı şiddetini daha yüksek düzeyde belirttikleri düşüncesiyle, sayısal ölçekler ile hassas ölçüm yapmanın sınırlı olabileceği belirtilmektedir. ${ }^{24}$ Buna rağmen, "Sayısal Ağrı Skalası"nın güvenilir ve sağlıklı bir ölçüm yöntemi olduğu çeşitli çalışmalarla desteklenmiştir. ${ }^{25}$ Hastalardan, son bir hafta içinde yaşadıkları en şiddetli ağrıyı ifade edebilecek sayısal değeri, skalada işaretlemeleri istenmiştir.

\section{BULGULAR}

Yaptığımız çalışmada uyguladığımız ölçeklere bağlı olarak elde edilen bulgular aşağıdaki tablolara göre değerlendirilecektir.

Tablo 3. Örneklemin Sayısal Ağr Skalası Puan Ortalaması

\begin{tabular}{|c|l|c|}
\hline \multirow{2}{*}{ Sayısal Ağrı Skalası } & N & ORTALAMA \\
\cline { 2 - 3 } & 360 & 27.63 \\
\hline
\end{tabular}

22 J. M. Black - E. Matasarrin Jacobs, Medical-Surgical Nursing, 4th Edition, London, WB Saunders Co., 1993, pp. 313-358; M. Tulunay-F.C. Tulunay, "Ağr1 Değerlendirilmesi ve Ağrı Ölçümleri”, A Agrr, ed. S. Erdine, Alemdar Ofset, İstanbul, 2000, ss. 91-107; Fatma Eti-Aslan, "Ağrı Değerlendirme Yöntemleri”, Cumburiyet Üniversitesi Hemșirelik. Yüksekokulu Dergisi, C. VI, S. 1, Sivas 2002, ss. 9-16.

23 Gillian A. Hawker et al., "Measures of Adult Pain", Arthritis Care \& Research, Vol. LXIII, No. S-11, 2011, pp.240-252; Asiye Özkan, "Kanser Hastalarında Ağr1 Değerlendirmesi”, XIII. TPOG Ulusal Pediatrik Kanser Kongresi, Hemşire Programı, 18-22 May1s 2004, ss. 189-192.

24 Aslan, a.g.m., ss. 9-16.

25 M. Gabrielle Pagé et al., "Validation of the Numerical Rating Scale for Pain Intensity and Unpleasantness in Pediatric Acute Postoperative Pain: Sensitive to Cahnge Over Time", The Journal of Pain, Vol. XIII, No. 4 (April), Seattle 2012, pp. 359-369; Maria Alexandra Ferreira-Valente et al., "Validity of Four Pain Intensity Rating Scales”, Pain, Vol. CLII, 2011, pp. 2399-2404. 
Yukarıdaki tabloda (Tablo 3) araștırmaya katılan meme kanseri kadın hastaların sayısal ağnı skalası puan ortalamalarının 27.63 olduğu görülmektedir. Sayısal ağrı skalasında en düşük puan “0”, en yüksek puan ise "100" olarak belirlenmiştir.

\begin{tabular}{|l|l|l|}
\hline \multicolumn{3}{|c|}{ Tablo 4. Örneklemin Beden Algısı } \\
\hline $\begin{array}{l}\text { FİZİKSEL GÖRÜNÜMDEN RAHATSIZLIK } \\
\text { DUYMA }\end{array}$ & & \\
\hline Evet (Olumsuz Beden Alg1si) & 84 & 23.3 \\
\hline Hayır (Olumlu Beden Alg1si) & 276 & 76.7 \\
\hline TOPLAM & $\mathbf{3 6 0}$ & $\mathbf{1 0 0 . 0}$ \\
\hline
\end{tabular}

Anket formunda yer alan "ameliyat sonrası fiziksel görüntüm beni rahatsız ediyor" ifadesi karşılaştırma yapabilmek amacıyla tüm hastalara yöneltilmiş ve bu ifadeye araştırmaya katılan meme kanseri kadın hastaların \% 23.3'ünün "Evet”, \% 76.7'sinin "Hayır" cevabı verdikleri tespit edilmiştir. Buna göre "Evet" cevab1 veren hastaların "Olumsuz Beden Alg1sı"na, "Hayır" cevabı veren hastaların ise "Olumlu Beden Algısı"na sahip oldukları düşünülmüsstür. Geçirilen ameliyata ve mastektomiye bağlı uzuv kaybının oluşturduğu fiziksel görünümdeki bozulmaya rağmen, araştırmanın örneklemini oluşturan meme kanseri kadın hastaların büyük çoğunluğunun (\% 76.7) olumlu beden algisına sahip oldukları görülmektedir. (Bkz. Tablo 4)

Tablo 5. Örneklemin Beck Depresyon Envanteri Puan Ortalamast ve Puan Dağgllım

\begin{tabular}{|c|c|c|}
\hline Puan Ortalaması & N & ORTALAMA \\
\hline Depresyon & 360 & 6.50 \\
\hline Puan Dağılımı & $\mathbf{N}$ & $\mathbf{\%}$ \\
\hline $0-4$ & 146 & 40.6 \\
\hline $5-10$ & 150 & 41.7 \\
\hline $11-17$ & 52 & 14.4 \\
\hline $18-19$ & 3 & 0.8 \\
\hline
\end{tabular}




\begin{tabular}{|c|c|c|}
\hline $20-35$ & 9 & 2.5 \\
\hline TOPLAM & $\mathbf{3 6 0}$ & $\mathbf{1 0 0 . 0}$ \\
\hline$<17$ & 46 & 96.1 \\
\hline$\geq 17$ & 14 & 3.9 \\
\hline TOPLAM & $\mathbf{3 6 0}$ & $\mathbf{1 0 0 . 0 0}$ \\
\hline
\end{tabular}

Tablo 5'te araştırmaya katılan meme kanseri kadın hastaların Beck Depresyon ölçeği puan ortalamalarının 6.50 olduğu görülmektedir. Tablodaki verilerden yola çıkarak örneklemin Beck Depresyon Ölçeği puan ortalamasının, tanımlanabilir depresyon düzeyine ulaşmadığı söylenebilir. Tablo 5'e göre hastaların \% 40.6'sinin (0-4) puan, \% 41.7'sinin (5-10) puan, \% 14.4'ünün (11-17) puan, \% 0.8'inin (18-19) puan, \% 2.5'inin (20-35) puan aralığında olduğu görülmektedir. Örneklemin \% 3.9'unun Hisli (1988) ${ }^{26}$ tarafindan Türk populasyonu için BDE'nin kesim noktası olarak belirlenen 17 puan ve üzerinde aldığı, \% 96.1'inin ise 17 puanın altında kaldığ1 tespit edilmiştir. Buna göre araştırmanın örneklemini oluşturan meme kanseri kadın hastaların yalnızca \% 3.9'unun tanımlanabilir depresyon düzeyinde oldukları söylenebilir.

\begin{tabular}{|c|l|c|}
\hline \multicolumn{3}{|c|}{ Tablo 6. Yaşam Kalitesi Ölçeği ve Boyutlar Puan Ortalaması } \\
\hline & N & ORTALAMA \\
\hline Fonksiyonel Boyut & 360 & 79.48 \\
\hline Semptom Kontrolü Boyutu & 360 & 20.56 \\
\hline Genel İyilik Hali & 360 & 69.61 \\
\hline
\end{tabular}

Araștırmanın örneklem grubunu oluşturan meme kanseri kadın hastaların EORTC QLQ C-30 Yaşam Kalitesi Ölçeği'nin Fonksiyonel Durum, Semptom Kontrolü ve Genel İyilik Hali boyutlarına ait puan ortalamaları Tablo 6'da gösterilmiştir. Yaşam kalitesi ölçeğinin boyutlarına ait puan aralığ $0-100$ 'dür. Fonksiyonel Durum ve Genel

${ }^{26}$ Nesrin Hisli, "Beck Depresyon Envanterinin Üniversite Öğrencileri İçin Geçerliliği, Güvenirliliği”, Psikoloji Dergisi, C. VII, 1989, ss. 3-13. 
İyilik Hali boyutlarındaki yüksek puanlar yaşam kalitesinin iyi düzeyde olduğunu; Semptom Kontrolü boyutunda ise yüksek puanlar, bu boyuta ait yaşam kalitesinin düşük seviyede olduğunu göstermektedir. Tablodaki verilere göre, örneklemin yaşam kalitesi boyutları puan ortalamaları; Fonksiyonel Durum (X=79.48), Semptom Kontrolü ( $X=20.56)$ ve Genel İyilik Hali ( $\mathrm{X}=69.61)$ şeklinde bulunmuştur. Fonksiyonel Durum ve Genel İyilik Hali puan ortalamalarının $(X=50)$ 'nin üzerinde olduğu, Semptom Kontrolü puan ortalamasinin ise $(X=50)$ 'nin altında olduğu görülmektedir. $\mathrm{Bu}$ durumda, örneklemin genel olarak yaşam kalitesi düzeyinin yüksek olduğu söylenebilir.

Tablo 7. Örneklemin Dini Tutum Ölçeği ve Boyutlar Puan Ortalaması

\begin{tabular}{|c|l|c|}
\hline & N & ORTALAMA \\
\hline Dini Tutum (Toplam) & 360 & 35.92 \\
\hline Dini Tutum - Davranış & 360 & 7.79 \\
\hline Dini Tutum - Duygu & 360 & 8.65 \\
\hline Dini Tutum - İlişki & 360 & 9.48 \\
\hline Dini Tutum - Biliş & 360 & 10.00 \\
\hline
\end{tabular}

Tablo 7'de araştırmanın örneklemini oluşturan meme kanseri kadın hastaların, araştırmada kullanılan Ok-Dini Tutum Ölçeği'ne ve alt boyutlarına ait puan ortalamaları görülmektedir. Dini tutum ölçeğinden alınabilecek en düşük puan " 0 ", en yüksek puan ise " 40 "; Dini Tutum Ölçeği alt boyutlarından alınabilecek en düşük puan " 0 ", en yüksek puan ise "10" olarak belirlenmiştir. Araştırmaya katılan hastaların Dini Tutum Ölçeği ve alt boyutlarına ait puan ortalamaları şöyledir: Dini tutum (toplam) $(\mathrm{X}=35.92)$, dini tutum "davranış" $(\mathrm{X}=7.79)$, dini tutum "duygu" $(X=8.65)$, dini tutum "ilişki" $(X=9.48)$, dini tutum "biliş" $(X=10.00)$. Tablodaki verilere bakıldığında, Dini Tutum Ölçeği alt boyutlarında en yüksek puan ortalamasının "biliş" alt boyutuna, daha sonra ise "ilişkik" alt boyutuna ait olduğu, en düşük puan ortalamasının ise "davranış" alt boyutunda olduğu görülmektedir. Araştırmada Dini Tutum Ölçeği'nin "bilişs" alt boyutuna ait önermelere, örneklemde yer alan tüm hastaların aynı cevapları vermesi ve dolayısıyla puanlarının aynı olması nedeniyle, 
"biliş" alt boyutu bir değişken olarak istatistiksel analizlere tabi tutulmamıştır.

Dini Tutum ve Diğer Bağımlı Değişkenler Arasındaki İlişki

\section{Dini Tutum ve Ağrı Algısı Arasındaki İlişki}

\begin{tabular}{|l|c|c|c|}
\hline \multicolumn{5}{|c|}{ Tablo 8. Dini Tutum ve Ağr Arasindaki Ilişki } \\
\hline & $\mathbf{N}$ & $\mathbf{r}$ & $\mathbf{P}$ \\
\hline Dini Tutum (Toplam) \& Ağr1 & 360 & -.024 & .646 \\
\hline Dini Tutum (Davranış) \& Ağrn & 360 & -.017 & .751 \\
\hline Dini Tutum (Duygu) \& Ağr1 & 360 & -.027 & .613 \\
\hline Dini Tutum (İlişki) \& Ağr1 & 360 & -.018 & .737 \\
\hline \multicolumn{5}{|c|}{$\mathrm{p}>0.05$} \\
\hline
\end{tabular}

Tablo 8'de alt boyutları ile birlikte dini tutum düzeyi ve ağr1 alg1s1 arasındaki ilişkiyi gösteren Pearson Korelasyon analizi bulgularına yer verilmiştir. Tablodaki verilere bakıldığında, dini tutum ve dini tutumun davranış, duygu ve ilişki alt boyutları ile örneklemin ağr1 algısı arasında anlamlı bir korelasyon olmadığı $(\mathrm{p}>0.05)$ görülmektedir. Bu durumda araştırmada, dini tutum ve ağrı arasında anlamlı bir ilişki bulunmadığ ifade edilebilir.

2. Dini Tutum ve Beden Alg1sı Arasındaki İlişki

Tablo 9. Dini Tutum İle Beden Algısı Arasındaki İlişkiye Yönelik Sonuclar

\begin{tabular}{|l|c|c|c|c|c|c|c|}
\hline $\begin{array}{l}\text { DİNİ } \\
\text { TUTUM } \\
\text { (TOPLAM) }\end{array}$ & N & Ort. & $\begin{array}{c}\text { Std. } \\
\text { S. }\end{array}$ & $\begin{array}{c}\text { Std. } \\
\text { H. }\end{array}$ & Sd & T & P \\
\hline (1) Olumlu & 276 & 36.21 & 3.182 & .192 & \multirow{7}{|c|}{$* 0.903$} & 3.216 & $\mathbf{. 0 0 2}$ \\
\hline (2) Olumsuz & 84 & 34.96 & 3.087 & .337 & $\mathbf{p}<\mathbf{0 . 0 1}$ \\
\hline TOPLAM & 360 & \multicolumn{7}{|c|}{} \\
\hline
\end{tabular}




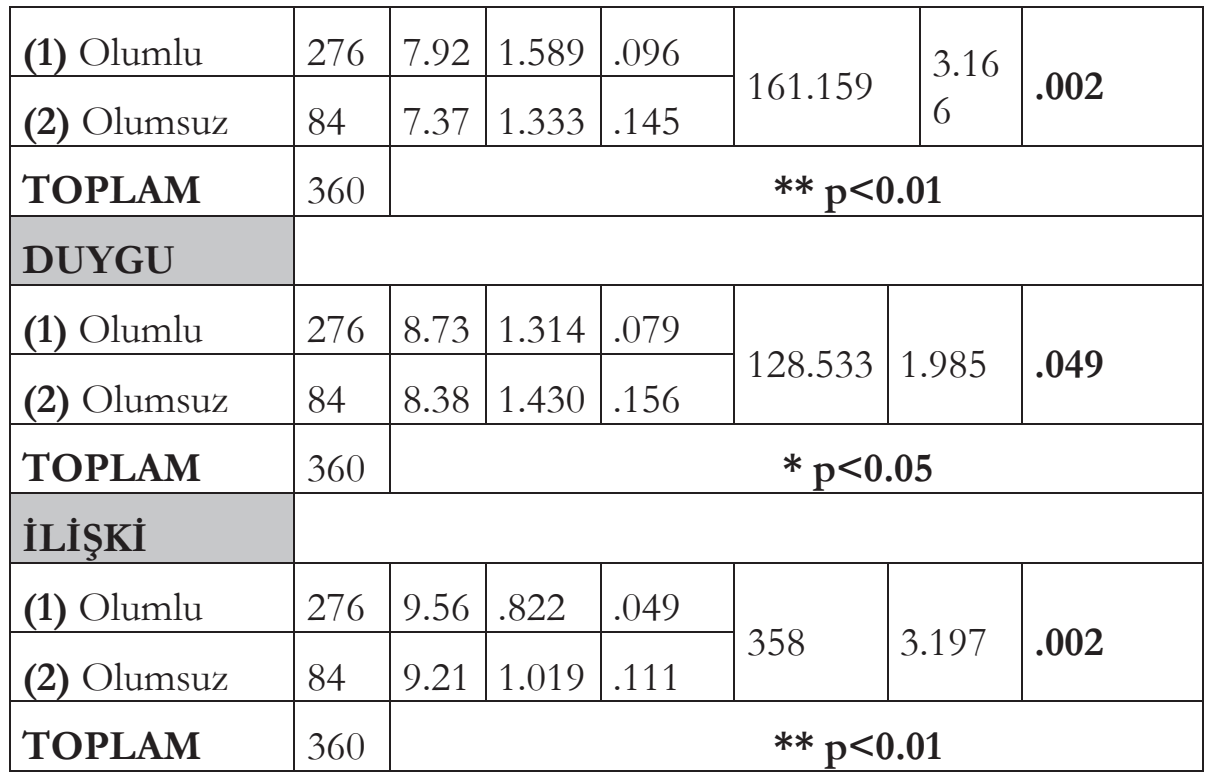

Tablo 9'da, örneklemi olușturan meme kanseri kadın hastalarda beden algisına göre dini tutum düzeyinin değişimini belirlemek amacıyla yapılan t-Testi sonuçları verilmiştir. Tablodaki verilere göre; olumlu beden algisına sahip olan hastaların $(X=36.21)$ dini tutum ölçeği toplam puan ortalamalarının, olumsuz beden algisina sahip hastalardan $(\mathrm{X}=34.96)$ anlamlı olarak $(\mathrm{t}=3.216 ; \mathrm{p}<0.01)$ daha yüksek olduğu bulunmuştur. Yine olumlu beden algisına sahip olan hastaların $(X=7.92)$ dini tutumun davranış alt boyutu puan ortalamalarının, olumsuz beden algisina sahip hastalardan $(\mathrm{X}=7.37)$ anlamlı olarak $(\mathrm{t}=3.166 ; \mathrm{p}<0.01)$ daha yüksek olduğu görülmektedir. Tablodaki verilere göre; olumlu beden algisina sahip olan hastaların $(\mathrm{X}=8.73)$ dini tutumun duygu alt boyutu puan ortalamalarinın, olumsuz beden algisina sahip hastalardan $(\mathrm{X}=8.38)$ anlamlı olarak $(\mathrm{t}=1.985 ; \mathrm{p}<0.05)$ daha yüksek olduğu belirlenmiştir. Ayrica olumlu beden algisina sahip olan hastalarin $(X=9.56)$ dini tutumun ilişki alt boyutu puan ortalamalarının, olumsuz beden algisina sahip hastalardan ( $\mathrm{X}=9.21)$ anlamlı olarak $(\mathrm{t}=3.197$; $\mathrm{p}<0.01)$ daha yüksek olduğu bulunmuştur. Dolayısıyla olumlu beden algisına sahip hastaların dini tutumun ilişki boyutunu, olumsuz beden algısına sahip hastalardan daha yüksek düzeyde yaşadıkları söylenebilir. 


\section{Dini Tutum ve Depresyon Arasındaki İlişki}

\begin{tabular}{|l|c|c|c|}
\hline \multicolumn{5}{|c|}{ Tablo 10. Dini Tutum ve Depresyon Arasindaki İiski } \\
\hline & $\mathbf{N}$ & $\mathbf{r}$ & $\mathbf{P}$ \\
\hline Dini Tutum (Toplam) \& Depresyon & 360 & $-.271 * *$ & $\mathbf{0 0 0}$ \\
\hline Dini Tutum (Davranış) \& Depresyon & 360 & $-.300^{* *}$ & $\mathbf{. 0 0 0}$ \\
\hline Dini Tutum (Duygu) \& Depresyon & 360 & $-.197 * *$ & $\mathbf{. 0 0 0}$ \\
\hline Dini Tutum (İlişki) \& Depresyon & 360 & $-.154^{* *}$ & $\mathbf{. 0 0 3}$ \\
\hline & $* *$ & $\mathbf{p}<\mathbf{0 . 0 1}$ \\
\hline
\end{tabular}

Tablo 10'da araştırmanın örneklemini oluşturan meme kanseri kadın hastalarda, tüm alt boyutları ile birlikte dini tutum düzeyi ve depresyon arasındaki ilişkiyi gösteren Pearson Korelasyon analizi sonuçları verilmiştir. Buna göre dini tutum ile depresyon arasında $(\mathrm{r}=-$ $.271 ; \mathrm{p}=.000)$ negatif yönde anlamlı bir ilişki; dini tutumun davranış alt boyutu ile depresyon arasında $(\mathrm{r}=-.300 ; \mathrm{p}=.000)$ negatif yönde anlamlı bir ilişki; dini tutumun duygu alt boyutu ile depresyon arasında $(r=-.197$; $\mathrm{p}=.000)$ negatif yönde anlamlı bir ilişki; dini tutumun ilişki alt boyutu ile depresyon arasında ( $\mathrm{r}=-.154 ; \mathrm{p}=.003)$ negatif yönde anlamlı bir ilişki olduğu bulunmuştur. Buna göre araştırma örnekleminde dini tutum düzeyi yükseldikçe, depresyon seviyesinin düştüğü söylenebilir.

\section{Dini Tutum ve Yaşam Kalitesi Arasındaki İlişki}

Tablo 11. Dini Tutum ve Yaşam Kalitesi Arasındaki İlişki

\begin{tabular}{|l|l|l|l|}
\hline & N & r & P \\
\hline Dini Tutum (Toplam) \& Fonksiyonel Durum & 360 & .090 & .090 \\
\hline Dini Tutum (Davranış) \& Fonksiyonel Durum & 360 & $.110 *$ & .037 \\
\hline Dini Tutum (Duygu) \& Fonksiyonel Durum & 360 & .041 & .438 \\
\hline Dini Tutum (İlişki) \& Fonksiyonel Durum & 360 & .069 & .192 \\
\hline \multicolumn{3}{|c|}{$*$ p<0.05 } \\
\hline Dini Tutum (Toplam) \& Semptom Kontrolü & 360 & .010 & .848 \\
\hline Dini Tutum (Davranış) \& Semptom Kontrolü & 360 & -.029 & .586 \\
\hline
\end{tabular}




\begin{tabular}{|l|l|l|l|}
\hline Dini Tutum (Duygu) \& Semptom Kontrolü & 360 & .056 & .292 \\
\hline Dini Tutum (İlişki) \& Semptom Kontrolü & 360 & .002 & .968 \\
\hline \multicolumn{4}{|c|}{$\mathrm{p}>0.05$} \\
\hline Dini Tutum (Toplam) \& Genel İyilik Hali & 360 & $.124 *$ & .019 \\
\hline Dini Tutum (Davranış) \& Genel İyilik Hali & 360 & $.142 * *$ & .007 \\
\hline Dini Tutum (Duygu) \& Genel İyilik Hali & 360 & .087 & .101 \\
\hline Dini Tutum (İlişki) \& Genel İyilik Hali & 360 & .067 & .202 \\
\hline \multirow{4}{|c}{$*$ p $<0.05$} & $\mathbf{0 0 . 0 1}$ \\
\hline
\end{tabular}

Tablo 11'de dini tutum ve yaşam kalitesi arasındaki ilişkiyi gösteren Pearson Korelasyon analizi sonuçları verilmiştir. Tablodaki veriler incelendiğinde; dini tutumun davranış alt boyutu ile yaşam kalitesinin Fonksiyonel Durum boyutu arasinda ( $r=.110 ; \mathrm{p}=.037)$ pozitif yönde anlamlı bir ilişki; dini tutum (toplam) düzeyi ile yaşam kalitesinin Genel İyilik Hali arasında ( $r=.124 ; \mathrm{p}=.019)$ pozitif yönde anlamlı bir ilişki; dini tutumun davranış alt boyutu düzeyi ile yaşam kalitesinin Genel İyilik Hali arasında ( $\mathrm{r}=.142 ; \mathrm{p}=.007)$ pozitif yönde anlamlı bir ilişki olduğu; dini tutum ve yaşam kalitesinin diğer boyutları arasında anlamlı bir ilişki olmadığ1 bulunmuştur. Bu durumda yüksek dini tutum düzeyinin, örneklemin yaşam kalitesi üzerinde olumlu bir etki oluşturduğu söylenebilir.

\section{TARTIŞMA VE SONUÇ}

Meme kanseri hastalarda ağr1, uzuv kayb1 (mastektomi), depresyon ve yaşam kalitesi üzerinde dindarlığın etkisini incelemek üzere tasarlanan bu çalışmada; dindarlı̆̆a ilişkin genel sonuçlara bakıldığında örneklemin dindarlık düzeyinin ortalamanın üstünde olduğu görülmektedir. Dini tutum ölçeği alt boyutlarında ise en yüksek puan ortalamasının "biliş" alt boyutundan sonra "ilişski" olması, ardından "duygu" ve en düşük puan ortalaması ile de "davranış" alt boyutunun gelmesi dikkat çekicidir. "İlişki”" alt boyutu, hastalar tarafindan genel olarak dua ve Allah'a yakınlaşma duygusu olarak algılanmıştır. Müslüman birey için dua etmenin ya da Allah'a yakarışta bulunmanın belli bir vakti ve mekanı yoktur. Daha da önemlisi kanserle başa çıkmada büyük güç ve 
destek olan dua ve Allah'a yakarış, hastalar için çaresizliklerine sığınak olan en büyük umuttur.

"Davranış" alt boyutunda meme kanseri hastalarda, dinin gereklerini yerine getirme ve yaşantılarında dini değerlere uyma dereceleri sorgulanmıştır. Birçok hasta için bu alt boyuta ait ölçekte yer alan ifadeler düzenli namaz kılma, oruç tutma, Kur'an-1 Kerim okuma gibi ibadetler ile İslam'ın çeşitli emir ve yasaklarını yerine getirme olarak düşünülmüştür. İnancin ve bilginin eyleme dönüştürülmesi bir insan için zorlu bir aşamadır. Dindarlık üzerine yapılan çeşitli çalışmalarda katılımcıların ibadet düzeni ve devamlılı̆̆ konusunda daha zayıf oldukları ve davranış boyutunun genel olarak diğer boyutların daha gerisinde olduğu yapılan pek çok araştırmada ortaya çıkmıştır. ${ }^{27} \mathrm{Bu}$ araştırmada da örneklem grubunun, ibadetlerin yerine getirilmesinde ve dini değerlere ilişskin yaşam biçiminde kendilerini düşük seviyede gördükleri ifade edilebilir.

Gerek meme kanseri tedavisinin yan etkileri olarak, gerekse ilerlemiş kanser vakalarında görülen fonksiyonel yetersizliğin de hastaların ibadetlerini düzenli olarak yapmalarına engel olduğu da gözlenmiştir. Ancak anket uygulaması sırasinda hastalarla yapılan küçük söyleşilerde birçok hastanın, İslam'ın ibadetleri yerine getirme konusunda sağladığ kolaylıklara ilişkin bilgiye (teyemmüm, yatarak ya da oturarak namaz kılabilme vb.) sahip olmadığı görülmüsstür. Hastaların bir kısmı, abdest almada fiziksel zorluk yaşadıkları için özellikle namaz kılamadıklarını hatta bazı hastalar namaz için ayakta durmaya halleri olmadığını belirterek namaz kılmayı bıraktıklarını ifade etmişlerdir. Bazı hastaların, namazı ve ibadetleri terk etmeden dolayı büyük bir pişmanlık ve günahkârlık duygusu içinde olduğu gözlenmiştir. Bu durumun ise hastalarda depresyona zemin oluşturabileceği ve manevi olarak cezalandırılmışlı ve uzaklaştırılmışlık duygularına yol açabileceği

27 Bkz. Ahmet Onay, Dindarlık, Etkileşim ve Değişim, Dem Yayınları, İstanbul, 2004, s. 162; Fatma Şengül, Dindarlık ve Ruh Sağllğı İlişkisi, Marmara Üniversitesi Sosyal Bilimler Enstitüsü, (Yayımlanmamış Yüksek Lisans Tezi), İstanbul, 2007, s. 119; Hülya Güven, Depresyon ve Dindarlık İlişkisi, (Yayımlanmamış Yüksek Lisans Tezi), Marmara Üniversitesi Sosyal Bilimler Enstitüsü, İstanbul, 2008, s. 99; Nurten Kımter, Benlik Saygısı ve Dindarlık İlişkisi, Uludă̆ Üniversitesi Sosyal Bilimler Enstitüsü, (Yayımlanmış Doktora Tezi), Bursa, 2008, s. 183. 
düşünülebilir. Bu durum, hastanelerde manevî danışmanlık hizmetlerine ne kadar çok ihtiyaç duyulduğunu göstermektedir.

Araştırmada ağr1 algısı ile dini tutum arasında (bkz. Tablo 8) bir ilişki bulunamadığ1 gibi örneklemin ağrı algısı puan ortalamasının da düşük olduğu görülmüştür. Bu sonucun oluşmasinda, örneklemin genel olarak ağr1 alg1sı düzeyinin düşük olmasının etkisi düşünülebilir. Ancak ilgili konuda yapılmış çalışmaların bir kısmında dua etmenin, Allah'a sığınmanın ağrıyla başa çıkmada etkili olduğu görülmüştür.

Galanter $^{28}$ (1982), Tanr1'ya güvenmenin, duanın ve inancın, ağr1 toleransını arttıran etkili bir yol olduğunu açılamıştır. Ağrıdan kurtulmada ve ağrının hafifletilmesinde bireysel yeterliliğin arttırılması ve spiritual ihtiyaçların sağlanmasının önemli olduğu belirtilmiştir. ${ }^{29}$ Babgi'nin (2010), Suudi kanser hastalarında ağrı ve başa çıkma davranışları üzerine yaptığı araştırmasında, ağrıyla başa çıkmada en fazla adaptif ve aktif davranış olarak dua etme (\% 99.2), Kur'an-1 Kerim okuma veya dinleme (\% 98.5) gibi dini pratiklerin yer aldığ1 tespit edilmiştir. ${ }^{30}$ Lucchetti ve arkadaşlarının (2011), yaşlı hastalarda (60 yaş üstü) dindarlık ile ruh sağlığı, ağrı ve yaşam kalitesi arasındaki ilişki üzerine yaptıkları çalışmada; hastaların \% 80.7'sinin ağrı tanımlaması yaptıkları belirlenmiştir. Araştırmada dindarlığın; düşük düzeyde ağr1 alg1s1, düşük düzeyde depresif semptomlar, daha iyi yaşam kalitesi ve düşük düzeyde bilişsel bozukluklar ile anlamlı ilişki gösterdiği bulunmuştur. ${ }^{31}$

Dolay1siyla elde edilen bulgulara göre "(H-1): Dini tutum ve dini tutumun davramıs, duygu, iliskei boyutlar ve ağrn algisı arasinda negatif yönde

28 M. Galanter, "Charismatic Religious Sects and Psychiatryan Overview", Am J Psychiatry, Vol. CXXXIX, 1982, pp. 1539-1548.

29 Fatemeh Haghighi, "Correlation Between Religious Coping and Depression in Cancer Patients", Psychiatria Danubina, Vol. XXV, No. 3, 2013, pp. 236-240.

30 Amani A Babgi, "Pain Coping Behaviors of Saudi Patients Suffering from Advanced Cancer : A Revisited Experience", Asian Pacific Journal of Cancer Prevention, Vol. XI (MECC Supplement), 2010, pp. 103-106.

31 G. Lucchetti et. al., "Religiousness Affects Mental Health, Pain, and Quality of Life in Older People in an Outpatient Rehabilitation Setting", Journal of Rehabilitation Medicine, Vol. XLIII, No. 4, 2011, pp. 316-322. 
anlaml bir iliski vardır." hipotezinin desteklenmediği ortaya çıkmıştır. (Bkz. Tablo 8)

Dini tutum (toplam) ve dini tutumun davranış, duygu ve ilişki alt boyutlarına ait puan ortalamalarının olumlu beden algisına sahip hastalarda daha yüksek çıkması da (bkz. Tablo 9) dindarlı̆̆ın, meme kanserinde uzuv (meme) kaybinin ya da fiziksel bozulmanın yol açabileceği olumsuzluklara karşı önemli bir koruyucu olduğu şeklinde açıklanabilir. Hastalık, uzuv kayıpları, engellilik gibi bedensel anormallik durumlarında dindar bireylerin "Allah'ın takdiri, imtihan, Allah'ın sevdiği kullarını hastalık ve sıkıntılara maruz bırakması vb." atıflar yaparak daha kolay başa çıktıkları ve yaşanılanları daha çabuk kabullendikleri söylenebilir. $\mathrm{Bu}$ durumda dini tutumun, olumlu beden imaj1 üzerinde etkili bir faktör olduğu düşünülebilir.

Meme kanseri kadın hastalarda, ameliyat sonrası kadınlığı temsil eden bir uzvun kaybina ve beden imajinın zedelenmesi fiziksel, ruhsal ve sosyal boyutları olan önemli problemlere neden olabilmektedir. Olumlu beden algısının, benlik yapısı ya da öz sayg1 (self-esteem) düzeyi ile ilişkili olduğu söylenebilir. İnsanda benlik yapısı, çevresini, diğer insanları ve kendisini görme ve alg1lama biçimini, varoluşun temelini oluşturduğu gibi tüm duygu, düşünce ve davranışları üzerinde de etkili olur. ${ }^{32}$ Öz sayg1 ya da benlik saygısı kişinin kendinden memnun olma duygusunun bir göstergesidir. Öz sayg1sı yüksek olan bireyler, kendilerini değerli, olumlu, beğenilmeye ve sevilmeye layık kişiler olarak görmektedirler. Aynı zamanda öz sayg1, kişinin kendini kabullenmesinde ve kendine güven duymasında etkili olan ve bu yönleriyle de bireysel ve sosyal hayata tesir eden önemli bir faktör olarak durmaktadır. ${ }^{33}$

Dolayısıyla kişinin kendi beden alg1sı ya da fiziksel görünüm imajının oluşmasında sahip olduğu öz sayg1 düzeyi diğer bir ifade ile benlik sayg1sı belirleyici bir etkendir. Literatürde, dindarlık öz sayg1 arasında olumlu ilişki olduğunu gösteren çalışmalar olduğu gibi ilişki olmadığını ya da negatif ilişki olduğunu gösteren çalışmalar da vardır. Gartner (1996), dindarlık ve öz sayg1 arasındaki ilişkiyi konu edinen 18

\footnotetext{
Çiğdem Kağıtçıbaşı, Yeni İnsan ve İnsanlar, Evrim Yayınevi, İstanbul, 1999, s. 360.

33 Asım Yapıc1-Salih Zengin, "İlahiyat Fakültesi Öğrencilerinin Dinin Etkisini Hissetme Düzeyleriyle Psiko-Sosyal Uyumları Arasındaki İlişki”, Cukurova Üniversitesi Illabiyat Fakültesi Dergisi, C. III, S. 2, Adana 2003, s. 104.
} 
empirik çalışmayı incelemiş ve bunların 6'sında yüksek ilişki, 4'ünde düşük ilişki olduğunu ve 8 'inde ise ilişki olmadığını tespit etmiştir. ${ }^{34}$

Kımter'in (2007) üniversite öğrencilerinde benlik sayg1s1 ve dindarlık ilişkisini incelediği çalışmasında, dini hayatın inanç boyutuyla benlik saygısı arasında pozitif yönlü anlamlı bir ilişki olduğu, dini hayatın inanç boyutunun benlik saygısı üzerinde olumlu yönde etkisi olduğu belirlenmiştir. ${ }^{35}$ Yoğurtçu'nun (2009) dindarlık ve ruh sağlı̆̆1 araştırmasında, dindarlık ve özsayg1 arasında negatif yönde anlamlı bir ilişki olduğu belirtilmiştir. ${ }^{36}$

Koenig, George ve Titus (2004) tarafindan yapılan araştırmada, dindar olmayan ve manevi bir yaşamı bulunmayan tıbbi tedavi gören yaşlı hastalarda, öz saygı düzeyinin ve öznel sağlık algısının, dindar hastalara göre daha düşük olduğu belirlenmiştir. Bu durum araştırmacılar tarafindan, dindarlık ve maneviyatın sağladığı sosyal destek ile açıklanmıştır. ${ }^{37}$

İstatistiksel analizler sonucunda; "(H-2): Dini tutum dïreyi ve dini tutumun davranış, duygu, iliskei boyutlar düzeyleri, olumlu beden algisina sabip hastalarda, olumsuz beden algisina sabip hastalara göre anlaml olarak daba yülksektir” hipotezinin desteklendiği görülmüştür. (Bkz. Tablo 9)

Araştırmada bir duygu durum bozukluğu olarak görülen depresyon ile dini tutum ve dini tutumun tüm alt boyutları arasında (bkz. Tablo 10) negatif yönlü anlamlı ilişkiler bulunmuştur. Bilindiği gibi

34 J. Gartner, "Religious Commitment Mental Health and Prosocial Behavior: A Review of the Emprical Literature", Religion and the Clinical Practice of Psychology, ed. E. P. Shafranske, American Psychological Association, Washington, 1996, pp. 187 214; (akt.) Asım Yapıc1, Ruh Sağh̆̆g ve Din: Psiko-Sosyal Uyum ve Dindarlık, Karahan Kitabevi, Adana, 2007, s. 100.

35 Nurten Kımter, Benlik Sayg1sı ve Dindarlık İlişkisi, Uludağ Üniversitesi Sosyal Bilimler Enstitüsü, (Yayımlanmamış Doktora Tezi), Bursa, 2008, s. 257.

36 Fatma Yoğurtçu, Yetişkinlerde Dindarlık ve Ruh Sağlığı, Sakarya Üniversitesi Sosyal Bilimler Enstitüsü, Sakarya, (Yayımlanmamış Yüksek Lisans Tezi), 2009, s. 70 .

37 H. G. Koenig - L. K. George - P. Titus, "Religion, Spirituality, and Health in Medically III Hospitalized Older Adults", Journal of the American Geriatrics Society, Vol. LII, No. 4, 2004, pp. 554-562; (akt.) Yapic1, a.g.e., s. 101. 
depresyon; umutsuzluk, karamsarlık, üzüntü, zevk alamama, çaresizlik vb. olumsuz duygularla karakterize çökkünlük hali olarak tanımlanır. Daha önce yapılan çalışmalarda, meme kanseri hastalarda genel olarak bu tür duyguların yoğun olarak yaşandığı ve depresif eğilimin yüksek olduğu tespit edilmiştir. Ancak bu araştırmada elde edilen bulgular, meme kanseri hastalarda dindarlık düzeyi arttıkça depresyonun azaldığını göstermektedir.

Bireylerin hastalıklar, güçlükler ve olumsuz durumlar karşısında dine, ibadete ve dua etmeye yönelmeleri içlerinde bulundukları durumu daha kolay atlatmalarına yardımcı olmaktadır. Din hayattaki stres verici olaylarin etkisini azaltarak, bireylerde olumlu duygu durumunun yükselmesini sağlar. ${ }^{38}$ Böylece insana güven ve ümit telkin eden dinin, umutsuzluğu engelleyerek depresyonun azalmasinda etkili olduğu ${ }^{39}$ söylenebilir.

Meme kanserli kadınlarda hastalıkla başa çıma sürecinde manevi boyutun, dindarlığın, dua etmenin, meditasyonun, Tanrı'ya sığınmanın önemli bir güç ve destek olduğunu gösteren çalışmalar mevcuttur. ${ }^{40}$ Literatürde, din ve depresyon ilişkisi üzerine yapılan çalışmalar farklı din ve kültürlere, dindarlığın boyutlarına ve dindarlık algısına göre farklılık gösterse de genel olarak dindarlık ve depresyon arasında negatif bir ilişki olduğu yönünde bulgular içermektedirler. Bu araştırmada dindarlık ve depresyona ilişkin elde edilen bulgu literatür ile uyumludur.

Koç'un (2002) ergenlerde dua ve ibadet psikolojisi ve ruh sağllğı ilişkisini araştırdığı çalışmasında, ergenlerin Allah'a olan inançları ile yaptıkları dua ve ibadetlerin hayatı zorluklarına katlanmada ve onlarla baş çıkabilmede oldukça etkili olduğuna inandıkları ve psikolojik rahatlama

38 Fatma Balc1, Psikolojik ve Öznel İyi Olma Hali ile Dini İnançlar Arasındaki İlişki Üzerine Bir İnceleme, Uludağ Üniversitesi Sosyal Bilimler Enstitüsü, (Yayımlanmamış Yüksek Lisans Tezi), Bursa, 2011, s.162.

39 Yap1c1, a.g.e., ss. 126-127.

40 B. R. Ferrell et al., "Quality of Life in Breast Cancer: Part II. Psychological and Spiritüel Well-Being”, Cancer Nursing, Vol. XXI, No. 1, 1998, pp. 1-9; SL. Fredette, "Breast Cancer Survivors: Concerns and Coping", Cancer Nursing, Vol. XVIII, No. 1, 1995, pp. 35-46; Veysi Ceylan, Meme Kanseri Olan Hastalarda Tanı Sonrasi Psikososyal Sorunlar, Dicle Üniversitesi Tıp Fakültesi, (Yayımlanmamış Uzmanlık Tezi), Diyarbakır, 2009. 
hissettikleri belirlenmiştir. ${ }^{41}$ Şengül'ün (2007) çalışmasında, dindarlığın bilgi-ibadet boyutu ile depresyon arasında negatif yönde anlamlı bir ilişki olduğu, bilgi-ibadet boyutu arttıç̧a depresif belirtilerde azalma olabileceği belirtilmiştir. ${ }^{42}$ Güven'in (2008) araştırmasında, örneklem grubunun öznel dindarlık alg1sı ve dini yönelimi arttıkça, depresyon düzeyinde azalma olduğu ve dindarlığın etki boyutu ile depresyon arasında negatif yönde anlamlı bir ilişki olduğu, dinden etkilenme derecesi arttıkça depresyon düzeyinde düşme olduğu tespit edilmiştir. ${ }^{43}$

Ceylan (2009) meme kanserinde psikososyal sorunları incelediği araştırmasında, zaman zaman intihar düşüncesinde olan hastaların, bu duruma engel olarak dini inançlarını gösterdiği ve hastalarda hastalığın gidişatında Yüce Allah'a olan bağlılığın etkin olduğu gözlenmiştir. Ceylan, araştırma sonucunda araştırma grubunda yer alan meme kanseri hastalarda psikolojik sorunların daha az gözlenmesini, hastaların güçlü aile ilişkisine ve eş uyumunun iyi oluşuna, maneviyatın (spiritual boyutun) sağlam olmasına ve psikolojik stresle başa çımada inanç duygusunun hakim olmasına bağlamıştır. ${ }^{44}$

Koenig ve arkadaşları ${ }^{45}$ (1992) tarafından yapılan çalışmada, demografik ve sağlığa ilişkin değişkenlerin kontrolünden sonra dini başa çıkma ve depresyon arasında negatif yönde anlamlı bir ilişki olduğu gözlenmiştir. Olson ve arkadaşlarının ${ }^{46}$ (2012) yaptığı araştırmada, olumlu

41 Mustafa Koç, Ergenlik Döneminde Dua ve İbadet Psikolojisinin Ruh Sağllğ1 Üzerindeki Etkileri, Uludağ Üniversitesi Sosyal Bilimler Enstitüsü, (Yayımlanmamış Yüksek Lisans Tezi), Bursa, 2002, s. 144.

42 Fatma Şengül, Dindarlık ve Ruh Sağllğı İlişkisi, Marmara Üniversitesi Sosyal Bilimler Enstitüsü, (Yayımlanmamış Yüksek Lisans Tezi), İstanbul, 2007, s. 148.

43 Hülya Güven, Depresyon ve Dindarlık İlişkisi, Marmara Üniversitesi Sosyal Bilimler Enstitüsü, (Yayımlanmamış Yüksek Lisans Tezi), İstanbul, 2008, s. 117.

44 Veysi Ceylan, Meme Kanseri Olan Hastalarda Tanı Sonrası Psikososyal Sorunlar, Dicle Üniversitesi Tıp Fakültesi, (Yayımlanmamış Uzmanlık Tezi), Diyarbakır, 2009, s. 50, s. 53.

45 H. G. Koenig et al., "Religious Coping and Depression Among Elderly, Hospitalized Medically Ill Men”, Am J Psychiatry, Vol. CXLIX, 1992, pp. 1693-1700.

46 M. M. Olson et al., "Religious Coping and Mental Health Outcomes: An Exploratory Study of Socioeconomically Disadvantaged Patients", Explore (NY), Vol. VIII, 2012, pp. 172-176. 
dini başa çıkmanın, daha iyi ruh sağlığını yordayıcı olduğu, buna karşılık olumsuz dini başa çıkmanın ise ruh sağlığ1 için karıştırıcı bir faktör olduğu bildirilmiştir. Ramirez ve arkadaşlarının ${ }^{47}$ (2012) hemodiyaliz hastalarında yaptığı çalışmada, olumlu ve olumsuz dini başa çıkmanın, böbrek yetmezliği ile başa çıkmada sıklıkla kullanıldığı bulunmuştur. Bu hastalarda, dini başa çıkma ile depresyon ve anksiyete arasında ve dini başa çıkma ile yaşam kalitesinin çok boyutlu yönleri arasında ilişki olduğu ancak olumlu dini başa çıkma ve psikolojik distress arasında bir ilişki olmadığ1 görülmüştür.

Haghighi'nin (2013), İranlı kanser hastalarında dini başa çıkma ve depresyon ilişkisini araştırdığı çalışmasında, Tanrı ile ilişki kurmayı dini başa çıkma metodu olarak kullanmanın depresyon düzeyinin düşük olmasında etkili olduğu ve ailesinin dini tutum düzeyi yüksek olan hastaların depresyon oranlarının düşük seviyede olduğu bulunmuştur. ${ }^{48}$

İstatistiksel analizler sonucunda elde edilen bu bulgu ile " $(\mathrm{H}-3)$ : Dini tutum ve dini tutumun davranıs, duygu, iliski boyutlar ve depresyon arasinda negatif yönde anlaml bir ilişki vardır" hipotezinin tümüyle desteklendiği görülmüsstür. (Bkz. Tablo 10)

Araştırmanın diğer önemli bulgularından biri, dini tutum (toplam) düzeyi ile yaşam kalitesinin Genel İyilik Hali arasında pozitif yönde anlamlı bir ilişki; dini tutumun davranış alt boyutu ile yaşam kalitesinin Fonksiyonel Durum ve Genel İyilik Hali boyutları arasında pozitif yönde anlamlı bir ilişki olduğunun bulunmasıdır (bkz. Tablo 11).

Araştırmada uygulanan yaşam kalitesi ölçeğinde "Fonksiyonel Durum" alt boyutu ile son bir hafta içinde hastaların günlük aktiviteleri yerine getirmedeki fiziksel yeterlilik ve bağımlılık düzeylerini göstermektedir. Meme kanseri hastalarında ameliyat tipine, tümörün yayılımına veya evresine göre koltuk altı lenf bezlerinin tamamı ya da bir kısmı alınabilmektedir. Bu hastalarda, lenf bezlerinin alındığı kolda zamanla lenf sıvısının birikmesine bağlı olarak lenfödem oluşabilmektedir. Lenfödem; kolda güçsüzlük, işlevsellikte azalma,

47 S. P. Ramirez et al.,"The Relationship Between Religious Coping, Psychological Distress and Quality of Life in Hemodialysis Patients", J Psychosom Res, Vol. LXXII, 2012, pp. 129-135.

48 Fatemeh Haghighi, "Correlation Between Religious Coping and Depression in Cancer Patients”, Psychiatria Danubina, Vol. XXV, No. 3, 2013, pp. 236-240. 
enfeksiyonlara açıklık gibi sorunlara neden olarak hastaların günlük yaşam aktivitelerinin kısıtlanmasına ve bağımlılığın artmasına yol açabilir. Meme kanseri kadın hastalarda, bu durum hastalığa ve tedaviye bağlı diğer semptomlarla birleștiğinde yaşam kalitesini hem fiziksel hem psikolojik olarak olumsuz yönde etkileyebilmektedir. Ayrıca kadın ve anne rolünün getirdiği sorumlulukları ve ev içi aktiviteleri de kısıtlayan fonksiyonel yetersizlik, sosyal alanda da yaşam kalitesini düşürür.

$\mathrm{Bu}$ araştırmada daha önce de belirtildiği gibi örneklemin dini tutum ölçeği alt boyutları arasında "davranış" boyutunda en düşük puan ortalamasına sahip olduğu görülmüştür. Meme kanseri hastalar, özellikle fonksiyonel yetersizlik ve güçsüzlük nedeniyle dini ibadetlerini yapmada zorluk yaşadıklarını ifade etmişlerdir. Dolayısıyla "davranış" ve "Fonksiyonel Durum" arasındaki bu ilişkinin oldukça anlaşılır ve anlamlı olduğu söylenebilir.

Araştırmada uygulanan yaşam kalitesi ölçeği "Genel İyilik Hali” boyutu, hastaların son bir hafta içindeki genel sağlık ve hayat kalitelerinin öznel değerlendirmesini içermektedir. Bu boyutun, hastaların kendi fiziksel sağlık alg1larına yönelik olduğu ifade edilebilir. Genel İyilik Hali boyutu ile dini tutum (toplam) ve dini tutumun davranış alt boyutu arasında pozitif ilişki olması, dindarlığın meme kanseri kadın hastalarda fiziksel sağlık algısına olumlu yönde katkı sağladığını gösteren önemli bir bulgudur. İslam Dini metinlerinde insanın iyi ve güzel hallerine şükür etmesi, sıkıntil hallerinde ise sabretmesi tavsiye edilmiştir. Hastalıkta ve sağlıkta yani her halde Allah'a hamd ve şükür içinde olunması ise övülmüştür. $\mathrm{Bu}$ yüzden Müslümanlar arasında şiddetli hastalık dönemlerinde dahi Allah'a şükretmek, acı ve 1zdıraptan dolayı şikayette bulunmamak yaygındır. Örneklem grubunda da hastalığa ait semptomlar (ağr1, bulant1, kusma vb.) yoğun olarak görülse de "Genel İyilik Hali" algilarının yüksek olabildiği gözlenmiştir. Nitekim bu araştırmada, yaşam kalitesinin "Semptom Kontrolü" boyutuyla dindarlık arasında anlamlı bir ilişki ortaya çıkmamıştır.

Bireysel iyilik halinin bir anlatımı olan yaşam kalitesinin, fiziksel ve sosyal iyilik, psiko-sosyal uyum, inanç ve değerlerden oluşan boyutları olduğu belirtilmektedir. Yaşam kalitesi aile, iş yaşamı ve sosyo-ekonomik 
koşullar gibi hayatın farklı alanlarında, bireyin günlük yaşamından aldığı doyum ve iyilik alg1sı olarak ifade edilebilir. ${ }^{49} \mathrm{Bu}$ durumda çok boyutlu olan yaşam kalitesi üzerinde, dini tutum ve davranışların olumlu yönde etki yapacağı düşünülebilir. Din ve maneviyatın, yaşam kalitesinin inanç boyutu içinde yer aldığı, dinin bireylerin psiko-sosyal uyumları, yaşam doyumları, ruh ve fiziksel sağllkları üzerindeki etkileri bir arada değerlendirildiğinde, din ve yaşam kalitesi arasında güçlü bir ilişki olduğu ortaya çıkmaktadır.

Örneğin; Yates ve ekibinin (1981) ileri düzeyde 71 kanserli hasta üzerinde yaptığı araştırmada, dini inanç ve eylemlerin daha az ağrıya, daha çok mutluluk ve doyuma sebep oldukları bulunmuştur. ${ }^{50}$ Kirkpatrick ve Shaver ${ }^{51}$ (1992), Tanrı'ya güvenli bağlanma göstermiş insanların, Tanrı'ya kaygılı bir şekilde bağlanmış olan insanlara göre yaşam doyumlarının daha yüksek, kayg1, depresyon ve fiziksel hastalık şikâyetlerinin ise daha düşük düzeyde olduğunu belirlemişlerdir.

Din, birtakım olaylarda özellikle bazı hastalıklarla başa çıkmada ve olaylara anlam vermede yardimc bir unsur olabilir. Nelson ve arkadaşları (2002) tarafından, kanser ve aids hastalarında yapılan bir çalışmada, dini başa çıkma etkinliklerinin hem acı ve sıkıntıya anlam verme hem de dayanma gücünü arttırma ve bir umut kaynağ1 olma konusunda önemli bir etkiye sahip olduğu görülmüştür. ${ }^{52}$

Yılmaz'ın (2006) kronik ağrilı hastalarda yaşam kalitesi araştırmasında ise kendini dindar olarak tanımlayan hastalarda, kendini dindar olarak tanımlamayan hastalara göre yaşam kalitesi fonksiyonel durum ve global yaşam kalitesi puanlarının düşük, esenlik ve genel sağlık

49 Nalan G. Beser - Fatma Öz, "Kemoterapi Alan Lenfomalı Hastaların AnksiyeteDepresyon Düzeyleri ve Yaşam Kalitesi”, Cumburiyet Üniversitesi Hemşirelik Yüksekokulu Dergisi, C. VII, S. 1, Sivas 2003, ss. 47-58.

50 Kenneth I. Pargament, "Tanrım Bana Yardım Et: Din Psikolojisi Açısından Başa Çıkmanın Teorik Çatısına Doğru”, çev. Ahmet Albayrak, Tabula Rasa-Felsefe Teoloji, Y. III, S. 9, Isparta 2003, s. 218.

51 L. A. Kirkpatrick - P. Shaver, "An Attachment-Theoretical Approach to Romantic Love and Religious Belief”, Personality and Social Psychology Bulletin, Vol. III, 1992, pp. 18-26; Akif Hayta, “Anneden Allah'a: Bağlanma Teorisi ve İslam'da Allah Tasavvuru”, Değerler Ë̆itimi Dergisi, C. IV, S. 12, İstanbul 2006, s. 41.

52 C. J. Nelson et al., "Spirituality, Religion and Depression in the Terminally Ill", Psychomatics, Vol. XLIII, No. 3, 2002, pp.213-220. 
puanlarının ise daha yüksek olduğu ancak bu puanlar arasında anlamlı farklılı̆̆ın olmadığı bulunmuştur. ${ }^{53}$ Arda'nın (2011), kanser hastalarında yaşamda anlamı incelediği çalışmasında, yaşamda anlam ile yaşam kalitesinin alt boyutlarından bedensel alan, ruhsal alan, sosyal alan, çevresel alan arasında pozitif yönde anlamlı bir ilişki olduğu bulunmuştur. $^{54}$

Gibson ve Hendrick (2006), hayatta kalan Afro-Amerikan meme kanseri hastalar üzerine 1994-2004 arası yapılmış çalışmalarda spiritualite etkisini incelemişlerdir. Bu literatür çalışmasında 18 yaş ve üstü hastalardan elde edilen bulgular sonucunda; koruyan ve himaye eden, kudretli ve şifa veren, karar vermede yol gösterici olan ve kendisiyle yakınlık kurulan Tanrı'ya olan inanç olarak tanımlanan durumlara ilişkin spiritualite/maneviyatın güçlü bir başa çıkma sağladığı belirlenmiştir. ${ }^{55}$ Morgan ve arkadaşlarının (2006), Afro-Amerikan meme kanseri kadın hastalarda yaşam kalitesi ile spiritual iyilik hali ve dini başa çıkma arasındaki ilişkiyi inceledikleri kesitsel araştırmada; hastalann pozitif dini başa çıkmayı, negatif dini başa çıkmadan daha fazla kullandıkları bulunmuştur. Ayrica spiritual iyilik hali ile yaşam kalitesinin fiziksel, emosyonel ve fonksiyonel iyilik hali boyutları arasında anlamlı ilişkiler olduğu belirlenmiştir. Elde edilen bulgulardan yola çııılarak meme kanseri kadın hastalarda, spiritual ve dini uygulamaların tedavi aşamasında destekleyici bir girişim olarak değerlendirilmesinin önemine dikkat çekilmiştir. ${ }^{56}$

O'Connor ve arkadaşlarının (2007), Avustralya'da 40 lösemi hastasında yaşam kalitesi, spiritual iyi olma ve psikolojik uyum tarzları

53 Eren Yılmaz, Kronik Ağrılı Hastalarda Yaşam Kalitesi, Marmara Üniversitesi Sağlık Bilimleri Enstitüsü, (Yayımlanmamış Yüksek Lisans Tezi), İstanbul, 2006, s. 70.

54 Şeyda Arda, Kanser Hastalarında Yaşamda Anlamın İncelenmesi, İstanbul Üniversitesi Sağlık Bilimleri Enstitüsü, (Yayımlanmamış Yüksek Lisans Tezi), İstanbul, 2011, s. 100.

55 L. M. Gibson - C. S. Hendricks, "Integrative Review of Spirituality in African American Breast Cancer Survivors", ABNF Journal, Vol. XVII, No. 2, 2006, http://www.ncbi.nlm.nih.gov/pubmed, (28.12.2014), pp. 67-72.

56 P. D. Morgan - F. G. Johansson - V. Mock, "Spiritual Well-Being, Religious Coping, and the Quality of Life African-American Breast Cancer Treatment: A Pilot Study", ABNF Journal, Vol. XVII, No. 2, 2006, pp. 73-77. 
arasındaki ilişkiyi inceledikleri araştırmada; spiritual iyi olma ve yaşam kalitesi arasında pozitif yönde anlamlı bir ilişki olduğu, ümitsizlik ve çaresizliğin ise hem yaşam kalitesi hem de spiritual iyi olma ile negatif yönde anlamlı bir ilişki gösterdiği bulunmuştur. Araştırmada yaşamak için bir nedeni olan, hayatını daha üretken hale getiren, yaşamda anlam, huzur, uyum, amaç ve güven duygusuna sahip olan, dini ve manevi inançlarında teselli bulan hastalarda, bu faktörlerin daha iyi bir yaşam kalitesine katkı sağladığı ifade edilmiştir. ${ }^{57}$

Levin ve arkadaşlarının (2009), meme kanseri kadın hastalarda duanın, iyilik hali ve ruhsal durum üzerindeki etkilerini inceledikleri araştırmada; katılımcıların \% 81'inin dua ettiklerini; dua etmenin kanser yaşantısında kadınlara yüksek düzeyde olumlu destek sağladığı belirlenmiştir. Araştırmada spiritualiteyi değerlendirmede kullanılan ölçme aracının; anlam ve amaç bulma, uyum ve huzur hissi, Tanrı'ya veya aşkın bir varlığa yakınlık gibi duyguların ifade edilmesine yönelik olduğu bildirilmiştir. Örneklemin anlam ve huzur bulma skorlarının diğerlerinden daha yüksek olduğu bulunmuştur. Genel spiritualitenin; yüksek düzeyde yaşam kalitesi (fiziksel iyilik hali, emosyonel iyilik hali, fonksiyonel iyilik hali) ve yüksek düzeyde sosyal destek ile pozitif yönde anlamlı ilisski ve yine depresyon ve anksiyete ile de negatif yönde anlamlı ilişki gösterdiği tespit edilmiştir. ${ }^{58}$

Stewart (2013) ve arkadaşları, tıp alanında klinik uygulamalarda birincil veya ikincil değissken olarak dini pratiklerin etkisini ele alan çeşitli çalışmaları incelemişlerdir. 49 çalışmayı değerlendiren araştırmacılar; dini inancin hastaların çoğu için oldukça önemli olduğunu, özellikle ciddi hastalıklarda ve bağımlı hastalarda pozitif başa çı kma mekanizması oluşturduğunu belirlemişlerdir. Elde edilen bulgulara göre hastalarda dini pratik sıklı̆̆ının ve Tanrı ile etkileşimin ön planda olabildiği ifade edilmiştir. Manevi/spiritual etkileşimin hastalarda; huzur duygusunun sağlanmasına, hastalığı anlamlandırmaya, hastalığa yüksek düzeyde uyum

57 M. O'Connor et. al., "Realationships Between Quality of Life, Spiritual Well-Being, and Psychological Adjustment Styles for People Living with Leukaemia: An Exploratory Study", Mental Health, Religion and Culture, Vol. X, 2007, pp. 631-647.

58 Ellen G. Levine, "The Benefits of Prayer on Mood and Well-Being of Breast Cancer Survivors", Support Care Cancer, Vol. XVII, No. 3, HillerØd 2009, pp. 295306. 
sağlamaya ve yaşam kalitesine olumlu yönde etki sağlayabileceği tespit edilmiştir. $^{59}$

İstatistiksel analizler sonucunda elde edilen bu bulguya göre " $\mathrm{H}$ 4): Dini tutum ve dini tutumun davrans, duygu, iliskei boyutlar ile yassam kalitesi fonksiyonel durum ve genel iyilik hali boyutlar arasinda pozitif yönde anlaml bir ilişki vardır" hipotezinin dini tutum-genel iyilik hali, dini tutum (davranıss)genel iyilik hali ve dini tutum (davranış)-fonksiyonel durum değişkenleri özelinde kısmen desteklendiği belirlenmiştir. (Bkz. Tablo 11)

Konuya ilişkin elde edilen diğer bulgular ise " $(H-5)$ : Dini tutum ve dini tutumun davramıs, duygu, iliskiki boyutlar ile yaşam kalitesi semptom kontroliu boyutu arasinda negatif yönde anlamle bir iliski varder" hipotezinin desteklenmediğini göstermektedir. (Bkz. Tablo 11)

Dini tutum ve diğer bulgular birlikte değerlendirildiğinde, meme kanseri kadın hastalarda, fiziksel ve ruhsal sağlığa etki eden çok sayıda faktörün olduğu ve bu faktörlerin birbirinden bağımsız olarak düşünülemeyeceğini göstermektedir. Bu ilişkiler ağının, insanın bedensel, psikolojik, sosyal ve manevi boyutları ile karş1l1klı etkileşim içinde olduğu söylenebilir.

Kisaca bu araştırmada, ana hipotez olarak belirlenen "meme kanseri kadm hastalarda dini tutum; ağrn algusi, uzuv kaybmm kabullenilmesi, depresyon ve yaşam kalitesi üzerinde olumlu yönde etkide bulunur" hipotezinin "ağr1 alg1s1" özelinde desteklenmediği ancak "uzuv kaybının kabullenilmesi (olumlu beden alg1s1)", "depresyon" ve yaşam kalitesinin "Fonksiyonel Durum" ve "Genel İyilik Hali" alt boyutlarında bağımsız değişkenlere bağlı olarak farklı ölçülerde desteklendiği görülmüştür.

Din, hayatın içinde yaşanılanların anlamlandırılmasında etkili olan, insana yaşamda anlam ve amaç sağlayan kutsal referanslar sistemidir. Örneğin, İslam dini, hayattaki her olayın bir hikmet ve kader çizgisinde meydana geldiğini, müminlere dünyanın bir imtihan yeri olduğunu ve insanların çeşitli sıkıntı ve hastalıklarla sınanacaklarını bildirir. Din sağlıkla ilgili her türlü tedbirleri almamıza ve gerekli koruyucu hekimlik hizmetlerine başvurmamıza rağmen başımıza

59 W. C. Stewart et al., "Review of Clinical Medicine and Religious Practice", Journal of Religion and Health, Vol. 52, No. 1, NY 2013, pp. 91-106. 
gelebilecek sikıntılara isyan etmeden sabredenlere mükâfat olarak Cennet'i vaat eder. $\mathrm{Bu}$ nedenle Müslüman bireyin dini motivasyonla kanser vb. olumsuz durumları anlamlandırmada ve hastalıkla başa çıkmada daha az zorlanacağı, genel sağlik algisının ve psiko-sosyal uyumunun da daha iyi olacağı söylenebilir. Kendisini Allah'ın iradesine teslim etmiş olan dindar insan, hayatın keder ve musibetlerinden emin olarak, güvenli bir limana sığınmış olur. Bu insan yaşadığı her türlü zorluk ve sıkıntı karşısında, Allah'a olan inancı ve bağlılığ1 vasıtasıyla hayata güzellik ve umut katarak yaşam doyumunu arttırabilir. 


\section{KAYNAKÇA}

Aaronson N. - Ahmedzai S. - Bergman B. , "For The European Organization For Research And Treatment Of Cancer Study Group On Quality Of Life. The European Organization For Research And Treatment Of Cancer Qlq-C30: A Quality Of Life Instrument For Use İn İnternational Clinical Trials In Oncology", J Natl Cancer Inst, Vol. LXXXV, N. 5, 1993.

Alacacıoğlu Ahmet, Kanser Hastası ve Hasta Yakınlarının Depresyon, Umutsuzluk ve Kayg1 Düzeylerinin Değerlendirilmesi, Dokuz Eylül Üniversitesi Tip Fakültesi, (Yayımlanmamış Uzmanlık Tezi), İzmir 2007.

Arda Şeyda, Kanser Hastalarında Yaşamda Anlamın İncelenmesi, İstanbul Üniversitesi Sağlık Bilimleri Enstitüsü, (Yayımlanmamış Yüksek Lisans Tezi), İstanbul 2011.

Ayten Ali ve diğerleri, "Dini Başa Çıkma, Şükür ve Hayat Memnuniyeti İlişkisi”, Din Bilimleri Akademike Araștorma Dergisi, C. XII, S. 2, Samsun 2012.

Babgi Amani A, "Pain Coping Behaviors of Saudi Patients Suffering from Advanced Cancer : A Revisited Experience", Asian Pacific Journal of Cancer Prevention, Vol. XI (MECC Supplement), 2010

Balcı Fatma, Psikolojik ve Öznel İyi Olma Hali ile Dini İnançlar Arasındaki İlişki Üzerine Bir İnceleme, Uludağ Üniversitesi Sosyal Bilimler Enstitüsü, (Yayımlanmamış Yüksek Lisans Tezi), Bursa 2011.

Beser Nalan G. - Öz Fatma, "Kemoterapi Alan Lenfomalı Hastaların Anksiyete-Depresyon Düzeyleri ve Yaşam Kalitesi", Cumburiyet Üniversitesi Hemşirelik. Yüksekokulu Dergisi, C. VII, S. 1, Sivas 2003.

Black J. M. - Jacobs E. Matasarrin, Medical-Surgical Nursing, 4th Edition, London, WB Saunders Co., 1993.

Ceylan Veysi, Meme Kanseri Olan Hastalarda Tanı Sonrası Psikososyal Sorunlar, Dicle Üniversitesi Tip Fakültesi, (Yayımlanmamış Uzmanlık Tezi), Diyarbakır 2009. 
Ekşi Halil, Başa Çıkma, Dini Başa Çıkma ve Ruh Sağllğı Arasındaki İlişki Üzerine Bir Araştırma: Eğitim, İlahiyat ve Mühendislik Fakültesi Öğrencilerinin Karşılaştırılması, Uludă̆ Üniversitesi Sosyal Bilimler Enstitüsü, (Yayımlanmamış Doktora Tezi), Bursa 2001.

Eti-Aslan Fatma, "Ağr1 Değerlendirme Yöntemleri”, Cumburiyet Üniversitesi Hemşirelik. Yüksekokulu Dergisi, C. VI, S. 1, Sivas 2002.

Ferreira-Valente Maria Alexandra et al., "Validity of Four Pain Intensity Rating Scales", Pain, Vol. CLII, 2011.

Ferrell B. R. et al., "Quality of Life in Breast Cancer: Part II. Psychological and Spiritüel Well-Being", Cancer Nursing, Vol. XXI, No. 1, 1998.

Fredette S. L., "Breast Cancer Survivors: Concerns and Coping", Cancer Nursing, Vol. XVIII, No. 1, 1995.

Galanter M., "Charismatic Religious Sects and Psychiatryan Overview", Am J Psychiatry, Vol. CXXXIX, 1982.

Gartner J., "Religious Commitment Mental Health and Prosocial Behavior: A Review of the Emprical Literature", Religion and the Clinical Practice of Psychology, ed. E. P. Shafranske, American Psychological Association, Washington 1996.

Gibson L. M. - C. S., "Integrative Review of Spirituality in African American Breast Cancer Survivors", ABNF Journal, Vol. XVII, No. 2, 2006, http://www.ncbi.nlm.nih.gov/pubmed, (28.12.2014).

Güven Hülya, Depresyon ve Dindarlık İlişkisi, (Yayımlanmamış Yüksek Lisans Tezi), Marmara Üniversitesi Sosyal Bilimler Enstitüsü, İstanbul 2008.

Güzelant A. et al., "The European Organization for Research and Treatment of Cancer C-30: An Examination into the Cultural Validity and Reliability of Turkish Version of the EORTC QLQC30", Eur J Cancer Care, Vol. XIII (2), 2004.

Haghighi Fatemeh, "Correlation Between Religious Coping and Depression in Cancer Patients", Psychiatria Danubina, Vol. XXV, No. 3, Zagrep 2013. 
Hawker Gillian A. et al., "Measures of Adult Pain", Arthritis Care \& Research, Vol. LXIII, No. S-11, 2011.

Hayta Akif, “Anneden Allah'a: Bağlanma Teorisi ve İslam'da Allah Tasavvuru”, Değerler Ë̆itimi Dergisi, C. IV, S. 12, İstanbul 2006.

Hisli Nesrin, "Beck Depresyon Envanterinin Geçerliliği Üzerine Bir Çalışma”, Psikoloji Dergisi, C. 6, S. 22, Ankara 1989.

Hisli Şahin Nesrin, "Beck Depresyon Envanterinin Üniversite Öğrencileri için Geçerliği, Güvenirliğì”, Psikoloji Dergisi, C. 7, S. 23, Ankara 1989.

Horozcu Ümit, “Tecrübi Araştırmalar Işığında Dindarlık ve Maneviyat ile Ruhsal ve Bedensel Sağlık Arasındaki İlişki”, Milel ve Nihal, C. VII, S. 1, İstanbul 2010.

Hökelekli Hayati, Din Psikolojisi, Türkiye Diyanet Vakfı Yayınları, Ankara 2010.

Kağıtçıbaşı Çiğdem, Yeni İnsan ve İnsanlar, Evrim Yayınevi, İstanbul 1999.

Kalayc1 Şeref, SPSS Uygulamah Çok Değişkenli Istatistik Teknikleri, Asil Yayın, Ankara 2010.

Kımter Nurten, Benlik Saygısı ve Dindarlık İlişkisi, Uludağ Üniversitesi Sosyal Bilimler Enstitüsü, (Yayımlanmış Doktora Tezi), Bursa 2008; Kriter Yay., 2012.

Kirkpatrick L. A. - Shaver P., "An Attachment-Theoretical Approach to Romantic Love and Religious Belief", Personality and Social Psychology Bulletin, Vol. III, 1992.

Koç Mustafa, Ergenlik Döneminde Dua ve İbadet Psikolojisinin Ruh Sağlığ1 Üzerindeki Etkileri, Uludağ Üniversitesi Sosyal Bilimler Enstitüsü, (Yayımlanmamış Yüksek Lisans Tezi), Bursa 2002.

Koenig H. G. - George L. K.. - Titus P., "Religion, Spirituality, and Health in Medically III Hospitalized Older Adults", Journal of the American Geriatrics Society, Vol. LII, No. 4, 2004.

Koenig H. G. et al., "Religious Coping and Depression Among Elderly, Hospitalized Medically Ill Men”, Am J Psychiatry, Vol. CXLIX, 1992. 
Köylü Mustafa, "Ruh ve Beden Sağllğı ile Din İlişkisi Üzerine Yapılan Araştırmaların Bir Değerlendirmesi”, Ondokuz Mayıs Üniversitesi İlahiyat Fakültesi Dergisi, S. 28, Samsun 2010.

Levine Ellen G., "The Benefits of Prayer on Mood and Well-Being of Breast Cancer Survivors", Support Care Cancer, Vol. XVII, No. 3, HillerØd 2009.

Lucchetti G. et. al., "Religiousness Affects Mental Health, Pain, and Quality of Life in Older People in an Outpatient Rehabilitation Setting", Journal of Rehabilitation Medicine, Vol. XLIII, No. 4, 2011.

Morgan P. D. - Johansson F. G. - Mock V., "Spiritual Well-Being, Religious Coping, and the Quality of Life African-American Breast Cancer Treatment: A Pilot Study", ABNF Journal, Vol. XVII, No. 2, 2006.

Musick M. A. et al., "Religious Activity and Depression Among Community-Dwelling Elderly Persons with Cancer: The Moderating Effect of Race", The Journal of Gerentology, Vol. LIII, No. 4, Philadelphia 1998.

Nelson C. J. et al., "Spirituality, Religion and Depression in the Terminally Ill”, Psychomatics, Vol. XLIII, No. 3, 2002.

O’Connor M. et. al., "Realationships Between Quality of Life, Spiritual Well-Being, and Psychological Adjustment Styles for People Living with Leukaemia: An Exploratory Study", Mental Health, Religion and Culture, Vol. X, 2007.

Ok Üzeyir, "Dini tutum Ölçeği: Ölçek Geliştirme ve Geçerlik Çalışması”, Uluslararası Insan Bilimleri Dergisi, C. VIII, S. 2, Sakarya 2011.

Olson M. M. et al., "Religious Coping and Mental Health Outcomes: An Exploratory Study of Socioeconomically Disadvantaged Patients", Explore (NY), Vol. VIII, 2012.

Onay Ahmet, Dindarlke, Etkilessim ve Değişim, Dem Yayınları, İstanbul 2004.

Özkan Asiye, "Kanser Hastalarında Ağrn Değerlendirmesi”, XIII. TPOG Ulusal Pediatrike Kanser Kongresi, Hemşire Program1, İzmir 18-22 May1s 2004. 
Özkan Sedat, "Meme Kanserli Hastaya Psikolojik Yaklaşım, Yaşam Kalitesi”, Meme Kanseri, ed. Erkan Topuz, İstanbul Üniversitesi, Onkoloji Enstitüsü Yayınları, İstanbul 1997.

Pagé M. Gabrielle et al., "Validation of the Numerical Rating Scale for Pain Intensity and Unpleasantness in Pediatric Acute Postoperative Pain: Sensitive to Cahnge Over Time", The Journal of Pain, Vol. XIII, No. 4 (April), Seattle 2012.

Pargament Kenneth I., "Tanrım Bana Yardım Et: Din Psikolojisi Açısından Başa Çıkmanın Teorik Çatısına Doğru”, çev. Ahmet Albayrak, Tabula Rasa-Felsefe Teoloji, Y. III, S. 9, Isparta 2003.

Ramirez S. P. et al.,"The Relationship Between Religious Coping, Psychological Distress and Quality of Life in Hemodialysis Patients", J Psychosom Res, Vol. LXXII, 2012.

Savaşır İskender - Hisli Şahin Nesrin, Bilişsel-Davranış̧ Terapilerde Değerlendirme: Sık Kullanılan Ölçekler, Türk Psikologlar Derneği Yayınları, Ankara 1997.

Sherman Allen C. - Simonton Stephanie, "Religious Involvement Among Cancer Patients", Faith and Health, ed. Thomas G. Plante - Allen C. Sherman, The Guilford Press, New York 2001.

Stewart W. C. et al., "Review of Clinical Medicine and Religious Practice", Journal of Religion and Health, Vol. 52, No. 1, NY 2013.

Şengül Fatma, Dindarlık ve Ruh Sağllğı İlişkisi, Marmara Üniversitesi Sosyal Bilimler Enstitüsü, (Yayımlanmamış Yüksek Lisans Tezi), İstanbul 2007.

T.C. Sağlık Bakanlığ1 Türkiye Halk Sağlığ1 Kurumu Kanser Daire Başkanlığ1, 2009 Kanser İnsidansları, GLOBOCAN 2012, http://www.kanser.gov.tr/daire-faaliyetleri/kanseristatistikleri.html, (07.04.2014).

Tarhan Nevzat, Inanç Psikolojisi, Timaş Yayınları, İstanbul 2009.

Tulunay M. - Tulunay F.C., "Ağnn Değerlendirilmesi ve Ağnı Ölçümleri”, A ğrr, ed. S. Erdine, Alemdar Ofset, İstanbul 2000.

Yapıc1 Asım - Zengin Salih, "İlahiyat Fakültesi Öğrencilerinin Dinin Etkisini Hissetme Düzeyleriyle Psiko-Sosyal Uyumları Arasındaki 
Depresyon Düzeylerinin Yaşam Kalitesi ve Dindarlı İle İlişkisi

İlişki”, Cukurova Üniversitesi İlabiyat Fakültesi Dergisi, C. III, S. 2, Adana 2003.

Yapıc1 Asım, Ruh Sağlı̆̆ ve Din: Psiko-Sosyal Uyum ve Dindarlı, Karahan Kitabevi, Adana 2007.

Yılmaz Eren, Kronik Ağrilı Hastalarda Yaşam Kalitesi, Marmara Üniversitesi Sağlık Bilimleri Enstitüsü, (Yayımlanmamış Yüksek Lisans Tezi), İstanbul 2006.

Yoğurtçu Fatma, Yetişkinlerde Dindarlık ve Ruh Sağllğ1, Sakarya Üniversitesi Sosyal Bilimler Enstitüsü, (Yayımlanmamış Yüksek Lisans Tezi), Sakarya 2009. 